\title{
Systemic Inflammatory Response and Atherosclerosis: The Paradigm of Chronic Inflammatory Rheumatic Diseases
}

\section{Aikaterini Arida *, Athanasios D. Protogerou, George D. Kitas and Petros P. Sfikakis}

First Department of Propaedeutic and Internal Medicine and Joint Rheumatology Program, National and Kapodistrian University of Athens Medical School, GR-115 27 Athens, Greece; athanprot@gmail.com (A.D.P.); george.kitas@nhs.net (G.D.K.); psfikakis@med.uoa.gr (P.P.S.)

* Correspondence: aridakater@yahoo.gr; Tel.: +30-213-206-1061; Fax: +30-210-746-2659

Received: 29 May 2018; Accepted: 20 June 2018; Published: 27 June 2018

\begin{abstract}
Patients with Chronic Inflammatory Rheumatic diseases (CIRD) are at increased risk of cardiovascular disease (CVD), ascribed not only to classical risk factors, but also to the presence of chronic systemic inflammatory response. Atherosclerosis, the cornerstone of CVD, is known to be accelerated in CIRD; rheumatoid arthritis promotes atheromatosis and associates with preclinical atherosclerosis equivalent to Diabetes Mellitus, which also seems to apply for systemic lupus erythematosus. Data on ankylosing spondylitis and psoriatic arthritis, albeit more limited, also support an increased CV risk in these patients. The association between inflammation and atherosclerosis, has been thoroughly investigated in the last three decades and the role of inflammation in the pathogenesis and progression of atherogenesis has been well established. Endothelial dysfunction, oxidative stress in vascular endothelial cells and macrophage accumulation, toll-like receptor signaling, NLPR-3 formation and subsequent pro-inflammatory cytokine production, such as TNFa, IL-1 $\beta$, IL-6, and TNF-like cytokine 1A, are few of the mechanisms implicated in the atherogenic process. Moreover, there is evidence that anti-inflammatory biologic drugs, such as anti-TNF and anti-IL1 $\beta$ agents, can decelerate the atherogenic process, thus setting new therapeutic targets for early and effective disease control and suppression of inflammation, in addition to aggressive management of classical CV risk factors.
\end{abstract}

Keywords: atherosclerosis; cardiovascular disease; inflammation; rheumatoid arthritis; lupus; ankylosing spondylitis; psoriatic arthritis

\section{Introduction}

Chronic Inflammatory Rheumatic diseases (CIRD), such as Rheumatoid arthritis (RA), systemic lupus erythematosus (SLE), and seronegative SpA, are associated with high prevalence of cardiovascular disease (CVD), leading to increased morbidity and mortality in patients [1-4]. In these populations, accelerated atherosclerosis, the cornerstone of CVD, is ascribed not only to classical CVD risk factors such as arterial hypertension, glucose intolerance, sedentary life, smoking and dyslipidemia, which are in several cases more prevalent in patients with CIRD, but also to the presence of chronic inflammation and perhaps disease-related therapies as well [1,5-7] (Figure 1).

Rheumatoid arthritis patients are known to have an increased risk of CVD compared to controls, equivalent to that of diabetes mellitus (DM). Moreover, given that existing CV risk assessment models used for the general population underestimate the CVD risk in RA, in 2009 the EULAR task force recommended that the CV risk estimate should be multiplied by 1.5 when certain disease characteristics are present, and this was subsequently carried over in the updated EULAR recommendations in 2017 
for all patients with RA [1,4,8-10]. Similarly, patients with SLE and/or antiphospholipid syndrome (APS) have been shown to have increased-at least 2- to 3-fold-mortality due to CVD events compared to the general population, which is not fully explained by classical risk factors included in the Framingham risk equation [11-13]. Studies examining subclinical CVD in SLE and APS patients reveal higher carotid intima-media thickness (cIMT) and the increased prevalence of atherosclerotic plaques, almost 2.5-fold compared to healthy controls [14-16]. As in RA, increased inflammatory burden, as well as immune dysregulation are thought to play a crucial role in plaque progression and promotion of CVD in these patients. Even though data is more limited, expanding evidence suggest an increased CVD morbidity and mortality in patients with ankylosing spondylitis (AS) and psoriatic arthritis (PsA), although the more frequent use of NSAIDs could contribute to this increase [4,17-22]. Interestingly, effective disease control and effective suppression of inflammation in these patients associates with less accelerated atherosclerosis, once again indicating that chronic inflammation has a detrimental effect on endothelial function, atherogenesis, and arterial stiffening (arteriosclerosis) [23,24].

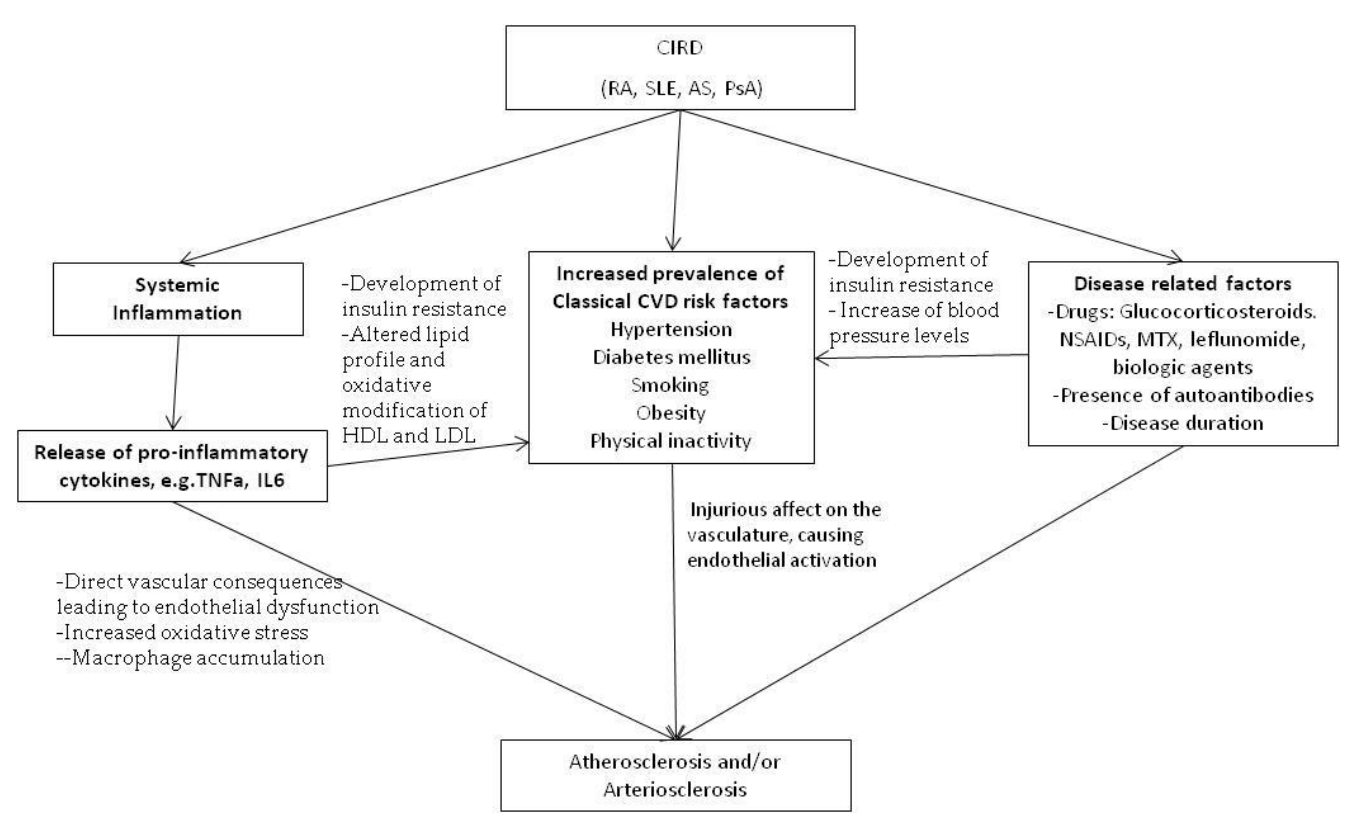

Figure 1. Risk factors involved in the pathogenesis of atherosclerosis and/or arteriosclerosis in chronic inflammatory rheumatic diseases.

The causal relationship between atherosclerosis and inflammation has been the subject of extensive investigation in recent years. Systemic markers of inflammation, such as C-reactive protein (CRP) and the proinflammatory cytokines TNFa and IL-6, are known to independently predict CVD events $[25,26]$ and the atherosclerotic process can be modulated by anti-inflammatory molecules targeting different inflammatory pathways [27]. Several lines of evidence suggest that CVD, from endothelial damage and atherogenesis to plaque rupture, is an immune-mediated disease and many studies have focused on determining the exact mechanisms involved in the atherosclerotic process. Alteration of lipoprotein concentrations, oxidative stress, and macrophage accumulation, as well as endothelial injury and dysfunction, activation of the innate immune system, and increased circulating cytokines are just a few of the underlying pathogenic mechanisms. Similarities of chronic inflammatory processes and the dysregulated immune responses seen in CVD and CIRD further support this association [28].

In the present narrative review, we summarize current knowledge regarding the prevalence of clinical and subclinical CVD in patients with RA, SLE, AS, and PsA and the common pathogenetic background between atherosclerosis and these CIRD, focusing to the underlying complex mechanisms of inflammation and immunity. We did not consider sclerodermia due to the very different nature 
of the disease and the different way in which it causes CVD. Regarding polymyalgia rheumatoca, a considerable difficulty is the relatively older age of the patients as well as the limited bibliography on the subject. Similarly, data on Sjogren's syndrome is very limited.

\section{Search Strategy}

We searched the Medline/Pubmed database for primary articles published through March 2018 on the association of CVD and CIRD, namely rheumatoid arthritis, systemic lupus erythematosus, ankylosing spondylitis, and psoriatic arthritis. More specifically, we included studies examining (a) the prevalence of CV events or subclinical CVD (endothelial dysfunction, arterial stiffness, arterial wall hypertrophy or atheromatosis), (b) the pathogenesis of atherosclerosis in CIRD in terms of the burden of chronic inflammation and immune dysregulation, as well as (c) studies reporting on the management of atherosclerosis via anti-inflammatory drugs. Search terms included: atherosclerosis, cardiovascular disease, intima-media thickness (IMT), pulse wave velocity (PWV), and atheromatic plaques in combination with inflammation, rheumatoid arthritis, lupus, ankylosing spondylitis, and psoriatic arthritis. We included prospective and retrospective, experimental or observational studies, systematic reviews, and meta-analyses, whereas comments were excluded. Abstracts presented in conferences were not considered.

\section{Thematic Sections}

\subsection{Epidemiology}

\subsubsection{Rheumatoid Arthritis}

The association of CVD and RA has been widely investigated in the past years and it is now well established that RA patients have an excess risk for developing CVD, comparable to that reported for patients with Diabetes Mellitus [8,9,29]. The increased prevalence of CVD refers to all components of atherosclerosis, from endothelial dysfunction and arterial stiffness to abnormal morphology and the formation of atheromatic plaques and CV events, namely myocardial infarction (MI) and stroke. A meta-analysis by Levy et al. concluded that RA patients present an excess risk of fatal MI compared to the general population and this risk was found to be similar in RA patients from a Danish cohort to that of patients with DM [10,30]. This was later verified for MI in a more recent meta-analysis [17] as well as for stroke in another meta-analysis involving 16 studies [31] (Table 1).

Table 1. Cardiovascular mortality and morbidity, subclinical cardiovascular disease, and classical cardiovascular risk factors in RA, SLE, AS, and PsA.

\begin{tabular}{|c|c|c|c|c|c|}
\hline & & RA & SLE & AS & PsA \\
\hline \multicolumn{2}{|c|}{ CVD risk or mortality } & $\begin{array}{c}\text { Comparative risk to } \\
\text { DM }[8,9,29] \\
\text { 1.5-fold risk compared to the } \\
\text { general population [1] } \\
\text { More than } 1.5 \text { risk of fatal } \\
\text { CV event [31] }\end{array}$ & $\begin{array}{c}\text { 2- to 3-fold mortality (up to } \\
16 \text {-fold) }[12,13]\end{array}$ & $\begin{array}{c}\uparrow \text { vs. controls } \\
{[32-34]}\end{array}$ & $\begin{array}{c}\text { Prevalence resembles that } \\
\text { of RA [35] } \\
\uparrow \text { mortality [32] }\end{array}$ \\
\hline \multirow{2}{*}{ CV events } & $\mathrm{CHD}$ & $\begin{array}{c}\text { Similar risk as DM [10] } \\
\text { 1.6-2.1 rate ratio for } \\
\text { MI }[17,30,31]\end{array}$ & $\begin{array}{l}\text { 2- to 3-fold risk (up to 52- } \\
\text { fold in young SLE women) } \\
{[12,13]}\end{array}$ & $\begin{array}{l}1.4 \text { relative risk of } \\
\mathrm{MI}[18,36]\end{array}$ & 1.4 relative risk of MI [17] \\
\hline & Stroke & 1.9 rate ratio $[31]$ & 2-fold risk $[12,13]$ & $\begin{array}{l}\text { 1.3-1.4 relative } \\
\text { risk }[18,36]\end{array}$ & $\begin{array}{c}\text { Similar or slightly } \\
\text { increased prevalence [37] }\end{array}$ \\
\hline \multirow{5}{*}{$\begin{array}{l}\text { Subclinical } \\
\text { CVD }\end{array}$} & cIMT & $\uparrow$ vs. controls [38] & $\uparrow$ vs. controls $[14,16]$ & $\uparrow$ vs. controls [23] & $\uparrow$ vs. controls [39] \\
\hline & PWV & $\uparrow$ vs. controls [40] & $\uparrow$ vs. controls [41-43] & $\begin{array}{c}\text { 个 vs. controls } \\
{[44,45]}\end{array}$ & $\uparrow$ vs. controls $[46,47]$ \\
\hline & FMD & $\downarrow$ vs. controls $[48,49]$ & $\downarrow$ vs. controls [16] & $\downarrow$ vs. controls [45] & $\downarrow$ vs. controls [39] \\
\hline & Aix & $\uparrow$ vs. controls [40] & $\uparrow$ vs. controls $[50,51]$ & $\begin{array}{l}\text { Similar to } \\
\text { controls [23] }\end{array}$ & - \\
\hline & Plaques & $\begin{array}{c}\uparrow \text { carotid vs. controls [38] } \\
\text { femoral analogous to DM [52] }\end{array}$ & $\begin{array}{c}\text { 2-fold risk [14-16], } \\
\text { comparable to RA and DM } \\
\text { [15] }\end{array}$ & $\begin{array}{l}\text { Similar to } \\
\text { controls [23] }\end{array}$ & 3-fold risk vs. controls [39] \\
\hline
\end{tabular}


Table 1. Cont.

\begin{tabular}{|c|c|c|c|c|}
\hline & RA & SLE & AS & PsA \\
\hline Classical Risk factors & $\begin{array}{ll}\text { - } \quad \uparrow \text { prevalence of HTN, } \\
\text { which underdiagnosed } \\
\text { and undertreated. } \\
\text { - } \quad \text { IR, associated with } \\
\text { disease activity TNFa } \\
\text { and IL6 levels } \\
\text { - } \quad \text { "Lipid Paradox" } \\
\text { - Oxidative changes to } \\
\quad \text { HDL structure } \\
\text { - } \quad \downarrow \text { physical activity } \\
\text { - } \quad \text { smoking }\end{array}$ & 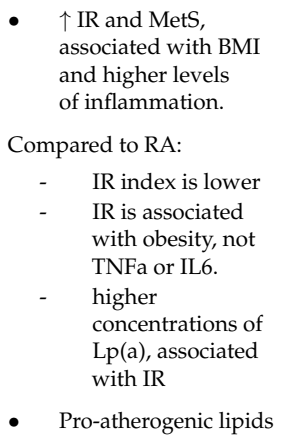 & $\begin{array}{ll}\text { - } & \uparrow \mathrm{BP} \text { levels } \\
- & \downarrow \text { HDL and } \\
& \text { TC levels, } \\
& \text { probably } \\
& \text { associated } \\
& \text { with TNFa } \\
\text { - } & \text { smoking } \\
\text { - } & \text { male gender }\end{array}$ & $\begin{array}{ll}\text { - } & \text { worse metabolic } \\
& \text { profile than RA or AS } \\
\text { - } & \uparrow \mathrm{BP} \text { levels } \\
\text { - } & \text { impaired } \\
\text { - } & \text { fasting glucose } \\
\text { - } & \uparrow \mathrm{HDL} \text { TC levels } \\
\text { - } & \text { central obesity } \\
\text { - } & \text { Similar to RA and AS: } \\
& \text { association with } \\
& \text { disease activity and } \\
& \text { TNFa levels }\end{array}$ \\
\hline
\end{tabular}

CVD: cardiovascular, DM: diabetes mellitus, CHD: coronary heart disease, MI: myocardial infarction, cIMT: coronary intima-media thickness, PWV: pulse wave velocity, FMD: flow mediated vasodilation, Aix: augmentation index, HTN: hypertension, IR: insulin resistance TNFa: tumor necrosis factor a, IL6: interleukin 6, HDL: high density lipoprotein, MetS: metabolic syndrome, BMI: body mass index, Lp(a): lipoprotein a, TC: triglycerides, vs.: versus. $\uparrow:$ increased, $\downarrow$ : decreased.

Ambrosino et al. in a meta-analysis concluded that RA patients have increased Pulse wave velocity (PWV) and Augmentation index (Aix) compared to controls and that alteration, present even in early-stage disease, was associated with the severity of the inflammatory status [40]. The same researchers showed that RA is associated with higher carotid intima-media thickness (cIMT) and increased presence of carotid atheromatic plaques [38]. Similarly, accelerated femoral atheromatosis was found to be analogous to DM in in a study by Protogerou et al. [52]. IMT progression in RA was associated with systemic inflammation and classical CVD risk factors in a study by del Rincon et al. [53], however, CVD progression was decelerated when RA disease inflammation was suppressed, indicating that chronic systemic inflammation alone has a substantial impact on promoting arterial disease in RA [54-56]. This is further supported by the fact that increased atherogenesis in RA has been shown to be independent of the presence of classical risk factors $[57,58]$. Finally, data from two recent meta-analyses found that endothelial function estimated by flow-mediated dilation (FMD) — considered as an independent predictor of CV events-is also impaired in patients with RA [48,49] (Table 1).

\subsubsection{Systemic Lupus Erythematosus and Antiphospholipid Syndrome}

The range of cardiovascular involvement in SLE includes atherosclerosis, vasculitis, Raynaud's phenomenon, and a pro-coagulant tendency associated with the presence of antiphospholipid antibodies. A recent meta-analysis found strong epidemiologic evidence of at least 2- to 3-fold elevated risks of a CVD event in patients with lupus compared to the general population, and this risk was alarmingly elevated in young women [13]. Paradoxically, while the risk of deaths related to lupus activity has decreased over time, the risk of deaths due to circulatory disease does not appear to have diminished [59] and this is further supported in a recent study by Tektonidou et al. by the fact that hospitalization of SLE patients for acute MI or stroke has not decreased [60] (Table 1).

Concerning subclinical atherosclerosis, $\mathrm{Wu}$ et al. in a meta-analysis including 80 studies that examined cIMT and carotid plaques, concluded that both indices were significantly increased compared to controls [14]. This was confirmed in a later meta-analysis, which also showed impaired FMD in SLE patients compared to controls [16], and further data support that FMD in SLE could serve as a marker of atherosclerotic vascular complications [61,62]. In addition, a study from our center revealed that the risk of atherosclerotic plaques in carotid, as well as femoral beds was comparable to that of DM and rheumatoid arthritis [15]. Similarly, arterial stiffness as measured by PWV and AIx has been proven to be increased in SLE patients compared to controls [41-43] and this is related to both traditional risk factors—especially metabolic syndrome and age—and SLE-related risk factors, such as disease activity 
measured by SLEDAI, SLICC damage index, higher C3 levels, presence of ds-DNA antibodies, and glucocorticoid therapy $[41-43,50,51,63,64]$ (Table 1).

\subsubsection{Ankylosing Spondylitis}

CVD results in increased mortality in AS, reaching a hazard ratio of 1.8 [24,32-34]. Studies have reported increased risk of acute coronary syndromes and stroke in patients with AS compared to controls and this was verified in a recent meta-analysis involving 18 studies $[18,36,65,66]$. Regarding subclinical atherosclerosis, our recent meta-analysis of 12 controlled studies found an increased overall IMT compared with matched controls, however, this was not evident in studies involving patients with low disease activity (mean BASDAI $<4$ ) or in those studies that included $>50 \%$ of patients treated with anti-TNF [23]. Interestingly, overall data from five studies revealed that carotid plaque burden was not increased in AS patients compared to controls. In the same study, common carotid artery stiffness as well as aortic stiffness were similar between cases and controls, in contrast to previous studies where aortic elasticity and endothelial dysfunction, estimated by PWV and FMD respectively, were impaired [23,44,45,67]. Again, arterial stiffness measured by Aix, was associated with C-reactive protein and AS disease activity score (ASDAS), supporting that disease activity is related to future risk of cardiovascular disease in patients with AS [68] (Table 1).

PsA patients are also considered to be of increased risk of cardiovascular morbidity and mortality compared with the general population [54]. Studies examining CVD in PsA found increased prevalence of CV events in PsA [20,21,37] and another study demonstrated that the prevalence of CVD in PsA resembles the $C V$ risk of $R A$ and the risk of CVD is associated with disease severity and disability index [35]. In a recent meta-analysis, the pooled relative risk of MI was 1.41 and it remained significantly increased after adjusting for traditional CVD risk factors [17], which could indicate the direct impact of PsA per se on the acceleration of CVD. Subclinical atherosclerosis has also been found to be increased in PsA. A recent meta-analysis by Di Minno et al. examining cardiovascular risk markers showed that carotid IMT, FMD, as well as atheromatic plaque index are higher in PsA patients than matched controls [39] and in some cases this was correlated positively with disease severity and negatively with the use of TNF-a blockers [69]. Carotid IMT and FMD were impaired even in the absence of classical risk factors in two small studies by Gonzalez-Juanatey et al. [70,71]. This was also the case in a study examining arterial stiffness by PWV in PsA patients without CV risk factors, which has also been reported to be increased in PsA [46,47] (Table 1).

\subsection{Classical Cardiovascular Risk Factors and Metabolic Syndrome (MetS)}

Inflammation can be a risk factor for developing MetS, as it can influence metabolic homeostasis. Metabolic syndrome can transiently occur in lean individuals during infection, where increased secretion of TNF, IL-6 and IL-1 by macrophages induces a temporary insulin-resistant state [72]. Regarding traditional risk factors such as hypertension, DM, smoking, hypercholesterolemia, obesity, and physical inactivity, they are commonly present in RA and this is likely to explain at least some of the excess CV risk in these patients [73]. RA patients have high prevalence of arterial hypertension, ascribed partially to the use of certain antirheumatic drugs such as corticosteroids, NSAIDs, cyclosporine, and leflunomide [74-77]. Interestingly, an easily modifiable risk factor such as arterial hypertension is not only under-diagnosed in RA, but also under-treated, further adding to the already excessive burden for CVD [78,79]. The increased presence of metabolic syndrome (MetS) in RA compared to controls, especially insulin resistance, is associated with disease activity and higher inflammatory markers, suggesting that inflammatory processes play a notable role in this case [80-82] (Table 1).

Several studies have shown that TNFa and IL-6 are involved in the development of insulin resistance $[83,84]$ and blocking of TNF-alpha activity with TNFa antagonists results in improved insulin sensitivity $[85,86]$. Moreover, the use of methotrexate independently correlates with a reduced propensity to MetS, whereas long-term glucocorticoid exposure does not seem to associate with a higher prevalence of the metabolic syndrome $[87,88]$. Of particular interest is the 'lipid paradox' of 
active RA, where the presence of excessive inflammatory burden leads to a decrease of total cholesterol, high-density lipoprotein (HDL) cholesterol, and low-density lipoprotein (LDL) cholesterol, while their CVD risk is elevated [89-91] (Table 1).

Moreover, chronic inflammation leads to oxidative changes that alter the HDL structure, causing an impairment to the normal anti-inflammatory, antioxidant, and cardioprotective function of HDL [92]. Paradoxically, anti-inflammatory therapies, especially TNFa inhibitors and methotrexate, coincide with an increase in an overall increase of lipid components, but mostly HDL, which improves the $\mathrm{TC} / \mathrm{HDL}$ ratio in patients with RA, and this lipid profile is associated with a reduction in the number of $\mathrm{CV}$ events, which is probably due to the anti-inflammatory effect and subsequent suppression of RA-associated inflammation [93-95]. The use of statins and n-3 fatty acids, apart from ameliorating the lipid profile and reducing the atherosclerotic burden, has anti-inflammatory properties that may result in an even greater CVD risk reduction [96-98] (Table 1).

Finally, the impaired physical activity in RA patients may also affect the risk of CVD, since low physical activity in RA women is associated with increased levels of oxidized low-density lipoprotein (oxLDL) and insulin, with reduced levels of HDL and atheroprotective antibodies against phosphorylcholine, and with insulin resistance [99]. Among traditional risk factors, smoking is not only an independent risk factor of atherosclerosis, but has also been associated with increased susceptibility to and worse prognosis of RA in individuals carrying shared epitope alleles and producing anti-citrullinatedprotein/peptide antibodies (ACPA) [100,101].

In SLE, insulin resistance (IR) is more prevalent than in controls and MetS was found to be associated with Body Mass Index (BMI) and higher levels of inflammation rather than lupus disease activity, damage scores, or the use of corticosteroids and antimalarial drugs [102]. Compared to RA, IR index is lower in SLE and the mechanisms underlying IR seem to differ between the two inflammatory diseases. Obesity seems to be an important factor in developing IR in SLE rather than in RA and IR in SLE is not associated with TNFa and IL-6 levels, as is in RA. Moreover, patients with SLE have higher concentrations of $\mathrm{Lp}(\mathrm{a})$, which is known to be associated to IR in some populations, than those with RA $[103,104]$. In addition, SLE patients have a tendency to develop pro-atherogenic lipids, which are aggravated by disease activity [105], as they show increased total cholesterol and triglycerides, decreased levels of normal HDL but a greater proportion of proinflammatory HDLs, and oxidized LDL (oxLDL) levels compared to healthy controls [106,107]. Since the use of statins seems to have a therapeutic effect not only on lipids, but also on fasting glucose and on CRP levels, control of dyslipidemia with statins in these patients could be of great importance (Table 1).

Although data is more limited, MetS prevalence has been found to be high in patients with AS and, as expected, was associated with disease activity, suggesting an association with the high inflammatory burden of the disease. More specifically, several studies, as well as a meta-analysis of 15 case-control studies, have shown that patients with AS have higher blood pressure levels, lower HDL, and triglyceride levels, are significantly more often smokers and, therefore, have higher atherogenic indices compared to controls $[19,108,109]$. This is compatible with current knowledge, since evidence supports a link between inflammatory cytokines such as TNFa, which is implicated in AS pathogenesis, and key components of HDL homeostasis and therefore an altered lipid profile. Regarding PsA, data suggests an even worse metabolic profile than that reported for RA or AS, with higher prevalence of impaired fasting glucose, low HDL cholesterol, high triglycerides level, central obesity, and high blood pressure compared to the other two diseases [21,110]. Again, correlation with disease activity [111] points to an adverse impact of high grade inflammation and particularly elevated TNFa levels, and data on the therapeutic use of biologic agents suggests a positive effect of TNFa inhibitors not only on articular and cutaneous symptoms, but also on the metabolic profile of these patients [112]. Data on the improvement of HDL function after successful psoriasis treatment [113] could also apply for PsA (Table 1). 


\section{Immunological Mechanisms}

\subsection{Endothelial Dysfunction}

Endothelial dysfunction is a necessary condition for the development of atherosclerosis. The endothelium is the key regulator of vascular homeostasis and low oxidative stress, as it is able to respond to physical and chemical signals by the production of a wide range of factors that regulate vascular tone, cellular adhesion, thromboresistance, smooth muscle cell proliferation, and vessel wall inflammation. The endothelium modulates vasomotion, by release of vasodilator substances, namely as nitric oxide (NO) and prostacyclin (PGI2), as well as via vasoconstrictor agents, such as endothelin, and via the conversion of angiotensin I to angiotensin II at the endothelial surface. Moreover, NO normally maintains the vascular wall in a quiescent state by inhibition of inflammation, cellular proliferation, and thrombosis.

Endothelial dysfunction is basically the maladaptive response of endothelial cells to pathological stimuli, mechanical or chemical. This results in endothelial activation; i.e., upregulated expression of cellular adhesion molecules (intercellular adhension molecule (ICAM)-1), ICAM-3, vascular endothelial adhension molecule (VCAM-1) at the endothelium favoring plaque formation, increased leukocyte diapedesis, increased vascular smooth muscle tone due to impaired processing of vasodilator substances, particularly NO, as well as increased production of vasoconstrictor substances, resistance to thrombosis via platelet aggregation, and oxidative stress upregulation [28,114,115]. Compromised barrier function, as a result of endothelial cell damage, leads to an increase in permeability to lipoproteins and plasma constituents, resulting in penetration of lipids into the arterial wall and subendothelial lipoprotein retention. These retained lipoproteins are subsequently taken up by macrophages to form foam cells and fatty streaks within the vessel wall [116]. Moreover, endothelial dysfunction leads to the accumulation of monocytes and proliferation of smooth muscle cells, which migrate to the lesion and lead to the thickening of the vessel wall and formation of fibrous tissue. Ultimately, a fibrous cap develops over the plaque, which, when becoming unstable, leads to rupture and subsequent thrombosis and CV events [117].

Endothelial dysfunction, while part of a normal immune system defense, can lead to atherogenesis and CV events as a result of prolonged and more intense inflammatory stimuli, which induces sustained endothelial activation. Both traditional and novel cardiovascular risk factors including smoking, aging, hypercholesterolemia, hypertension, hyperglycemia, as well as obesity, elevated CRP, and chronic systemic infection, are all associated with alteration in endothelial function [118]. As previously mentioned, in CIRD, classical risk factors are more prevalent and therefore have a more injurious effect on the vasculature. Moreover, autoimmune-inflammatory mechanisms include the accumulation of inflammatory molecules (lymphocytes and macrophages), presence of autoantibodies, and the secretion of pro-inflammatory cytokines, chemokines and adhesion molecules, which have systemic vascular consequences and subsequently reduce synthesis of $\mathrm{NO}$, initiating the cascade of events leading to endothelial dysfunction and CVD [117,119]. Several studies have focused recently on the correlation between such biomarkers indicative of endothelial dysfunction and CVD in patients with CIRD, particularly RA and on how biologic therapy influences these markers associated with the development of CVD. Dessein et al. showed that serum levels of VCAM-1 were associated with common cIMT and plaque presence and IL-6 was independently related to endothelial activation $[115,120,121]$. VCAM-1 was also partially correlated with cIMT in RA patients undergoing Infliximab therapy, but this was not evident for carotid plaques or other biomarkers of endothelial cell activation, even though anti-TNF treatment seems to reduce the serum levels of ICAM-3 and P-selectin molecules [122,123]. In another study by Kerekes et al., impaired endothelial function, measured by flow-mediated dilation (FMD), was associated with IFN- $\gamma$ levels in RA patients [124]. Asymmetric dimethylarginine (ADMA) levels - an inhibitor of nitric oxide (NO) synthase and a possible marker of endothelial dysfunction-are found elevated in RA patients, and this was associated with increased inflammatory markers, even though there seems to be no correlation with in vivo assessments of vascular function 
and morphology $[115,125]$. Regarding SLE, data is more limited, but studies have shown increased levels of certain soluble endothelial damage biomarkers, such as ICAM-1 and thrombomodulin (TM) in SLE women and VCAM-1 in patients with lupus nephritis [126,127] Similarly, AS studies indicate that increased levels of ICAM-1, TM and IL-6, as well as increased ADMA serum concentrations are not correlated however with disease activity [128-130]. In PsA, both ICAM-1 and VCAM-1 levels have been found to be increased compared to controls and ICAM and IL6 were correlated with Cimt [131,132].

\subsubsection{Oxidative Stress}

Oxidative stress reflects the imbalance between the production of reactive oxygen species (ROS) and impaired antioxidant capability, which in turn causes cell injury by directly oxidizing cellular protein, lipid, and DNA or via cell death signaling pathways. Oxidative stress has been demonstrated to play an important role in the pathogenesis of atherosclerosis especially by promoting the oxidative modification of LDL. Oxidized LDL takes part in many phases of atherogenesis: stimulates the binding of monocytes to the endothelium, foam cell formation, the development of plaques, plaque destabilization, and thrombotic complications [28,133].

Oxidative stress and inflammation are interrelated and this interaction promotes plaque formation and rupture. Increased oxidative stress is thought to play a role in the pathophysiology of inflammatory diseases such as RA and SLE, contributing to immune system dysregulation and autoimmunity $[119,134]$. In RA, the overproduction of TNFa is a main contributor to increased ROS release, and this is related to disease activity. ROS conserves oxidative stress, further promoting in this way cell damage and atherogenesis $[135,136]$. Moreover, oxidative modification of LDL has been linked to TNFa action and HDL constituents may be altered by the inflammation, thus losing their ability to remove cholesterol from atherosclerotic lesions and reducing their antioxidant activity. As previously mentioned, in SLE there is a decrease in normal HDL and a greater proportion of proinflammatory HDLs, which impairs the ability to prevent LDL oxidation [107]. Similarly, studies showed increased levels of oxidative stress markers with AS [137,138] and PsA [139], however, data is limited. Interestingly, control of disease activity via the use of TNFa inhibitors in RA can reduce oxidative stress [140], probably also directly reducing in this way the risk of CVD.

\subsubsection{Innate Immunity, Toll Like Receptor (TLR) Signaling, and NLRP3 Inflammasome Activation}

Innate immune mechanisms play a central role in atherogenesis, involving the activation of pattern-recognition receptors (PRRs), especially damage-associated molecular patterns (DAMPs), on the surface of ECs, and the induction of inflammatory processes and atherogenesis [141]. Scavenger receptors expressed by macrophages recognize specific epitopes of oxidized LDL and mediate clearance of lipoproteins and intracellular cholesterol accumulation, thereby promoting foam cell formation.

Signaling through the Toll like receptor (TLR) pathway has been implicated in the pathogenesis of autoimmune diseases, including RA, SLE and SpA, as well as in atherosclerosis. TLRs are membrane glycoprotein PRRs that recognize both PAMPs and DAMPs and initiate complex signal transduction pathways that mediate strong inflammatory responses. They are widely expressed on many cell types such as ECs, macrophages, dendritic cells, lymphocytes, and vascular smooth muscle cells, all of which are implicated in atherosclerotic lesion development. Atherosclerotic lesions display enhanced expression of specific TLRs, especially TLR2 and TLR4, on the surface of ECs. In atherosclerosis, an oxidized LDL can trigger TLR signaling, thus mediating macrophage accumulation and infiltration, induction of proinflammatory cytokines, activation of inflammatory cells, and decreased presence of regulatory $\mathrm{T}$ cells in the atherosclerotic lesions, conditions which are known to promote atherogenesis $[117,142,143]$.

In RA, there is the pathogenic expression of inflammatory cytokines- including TNF- $\alpha$, IL-1, and IL-6-by synovial macrophages and an increasing body of evidence supports the role of TLRs in the persistent, progressive activation of macrophages. Several studies have shown an increased expression of different TLRs by cells within the RA joint, as well as an increased responsiveness of RA synovial 
fibroblasts and RA synovial macrophages to microbial TLR ligands [144-146]. Therefore, both RA and atherosclerosis are characterized by chronic inflammation, the accumulation of macrophages, dendritic cells, and B and T lymphocytes caused by the local expression of TLRs and potential endogenous TLR ligands. Moreover, the release of endogenous TLR ligands as well as cytokines, such as TNFa and IL-6, from the inflamed synovial tissue might further activate macrophages in the atherosclerotic plaque and partly explain the increased occurrence and severity of atherosclerosis in RA [144].

In SLE, evidence suggests that the TLR system enhances the expression of pathogenic autoantibodies and possibly contributes to the IFN- $\alpha$ signature pattern that is characteristic of patients with active SLE [147]. More specifically, the release of IFN- $\alpha$ from plasmacytoid dendritic cells in patients with lupus may be mediated by the activation of TLR7 and TLR9 by endogenous RNA and DNA. Further, the release of IFN- $\alpha$ systemically may also promote the activation of macrophages in the atherosclerotic plaques by endogenous TLR2 and TLR4 ligands that are expressed locally. It is also possible that in patients with lupus and atherosclerosis, the plaque dendritic cells may also become activated by coming into contact with RNA- or DNA-containing immune complexes [144].

Regarding AS and PsA, emerging evidence indicates that TLRs play a potential role in the pathogenesis of SpA, which is supported by the fact that certain TLRs have been found to be overexpressed in patients with AS and PsA. De Rycke et al. showed increased TLR4 expression in peripheral blood mononuclear cells from patients with AS, as well as increased TLR2 and -4 expression in the inflamed synovium of patients with SpA (including PsA, AS and undifferentiated spondyloarthritis) compared with osteoarthritis or RA synovium, which was sharply reduced by TNFa blockade [148]. Similarly, Assassi et al. showed the upregulation of gene expression of TLR4 and 5 in AS but not in healthy controls or systemic lupus erythematosus patients and Candia et al. found the increased expression of TLR2 in immature dendritic cells in patients with PsA $[149,150]$. As in RA and SLE, it is probable that engagement of TLRs activates inflammatory cells and promotes secretion of pro-inflammatory cytokines, such as IL-6, TNFa, and type I IFNs, which not only drive inflammation in AS, but also could further activate macrophages in the atherosclerotic plaques and thus promote atherogenesis.

Recently, there is much interest in the possible role of NOD-like receptor family pyrin domain containing 3 (NLRP3) inflammasome in atherosclerosis. The NLRP3 inflammasome is an intracellular signaling molecule that, after being stimulated by TLRs and NFkB, activates caspase-1, which in turn cleaves the pro-inflammatory cytokines IL- $1 \beta$ and IL-18 to their active forms, known to play a vital role in promoting the development of lipid plaques and destabilizing the plaques [151,152]. In a study by Altaf et al. NLRP3 and downstream cytokine expression were increased in the peripheral blood of patients with acute MI and unstable angina compared to controls and this was modulated by high dose rosuvastatin [153]. High expression of NLRP3 was also evident in carotid atherosclerotic plaques and this was associated with plaque vulnerability [154]. The implication of NLRP3 in atherogenesis is further supported by the fact that the inhibition of NLRP3 reduced plaque formation and decelerate atherosclerosis in mice [155]. Studies have shown NLRP3 is activated by cholesterol crystals and releases IL-1 $\beta$ [156,157], also demonstrating that the deposition of crystalline cholesterol in arteries or elsewhere is an early cause rather than a late consequence of inflammation.

NLRP3 inflammasome, being an important component of the inflammatory process, has also been shown to have major involvement in the development of CIRD. Several studies have implicated the activation of NLRP3 and subsequent IL- $1 \beta$ secretion in the pathogenesis of RA, as NLRP3 gene expression and caspase- 1 and IL- $1 \beta$ levels were elevated in patients with active RA $[158,159]$. Finally, a study by Kastbom et al. showed that Genetic variants of the NLRP3 inflammasome increased the risk of stroke/transient ischemic attack in RA patients [160]. In patients with SLE, studies have shown elevated circulating IL-18, IL-1 $\beta$ and IL-17, as well as hyperactive NLRP3 inflammasome and caspase-1 in peripheral blood monocyte cells and lupus nephritis biopsies, and this was correlated with serum levels of anti-dsDNA antibodies and disease activity and even linked to lupus nephritis [161,162]. Immune complexes formed secondary to antibody recognition of DNA or RNA antigens and C3a have 
been shown to stimulate inflammasome activation through the upregulation of TLRs and upregulation of ATP secretion, respectively $[163,164]$. Regarding the association with CVD, type I IFNs present in SLE are considered to have a detrimental impact on the vasculature that promotes atherosclerosis, and this is done by upregulation of NLRP3, caspase-1, and IL-18 in endothelial progenitor cells [165]. Moreover, Samstad et al. recently suggested that complement activation may contribute to atherosclerosis development via enhancement of NLRP3 inflammasome by cholesterol crystals, which accumulate in atherosclerotic plaques [166]. In AS, data is scarce and contradictory concerning the role of NLRP3 inflammasome in pathogenesis, as Zhao et al. reported association with AS susceptibility [167], whereas Kastbom A et al. found no association between them [160].

\subsubsection{Macrophage Accumulation}

Macrophages are fundamental contributors in the development and progression of atherosclerosis. Atherosclerosis begins with a fatty streak, which is made up almost entirely of monocyte-derived macrophages. Macrophages and monocytes ingest oxidized LDL, transform into foam cells, and recruit additional monocytes and macrophages to the vessel wall. The development of an atheroma continues as other inflammatory cells are recruited to the intima and as smooth muscle cells proliferate, thereby increasing the lesion size [28,168].

The accumulation of macrophages at the site of inflammation producing inflammatory mediators serve as a prominent feature in both systemic inflammation and atherosclerosis. In both RA and SLE macrophage activation, as reflected by serum neopterin concentrations $[169,170]$, is increased compared to controls. This increase was more robustly associated with mediators of inflammation in SLE rather than RA, however, this could be attributed to IFN- $\gamma$, which induces neopterin formation and is known to be implicated in the pathogenesis of SLE. In the same study, the lower concentrations of neopterin found in patients with SLE taking antimalarials and in those with RA taking MTX suggest that these drugs may inhibit monocyte and macrophage activation [171]. In another study by Voloshyna et al. [172], the presence of RA plasma induced pro-atherogenic changes in gene expression and was associated with augmented lipid accumulation and foam cell formation by macrophages, suggesting that chronic exposure to RA plasma adversely affects the capacity of monocytes/macrophages in the arterial wall to metabolize cholesterol and maintain lipid homeostasis, thereby contributing to the development of premature atherosclerosis.

In SLE, priming of IFN $\alpha$, which plays a pathogenic role in the disease, promotes lipid uptake and macrophage-derived foam cell formation, indicating that the IFN signaling pathway may be linked to the risk of atherosclerosis by affecting plaque formation in patients with SLE [173]. Moreover, recent data show a different regulation of gene expression in mononuclear cells during monocyte-to-macrophage differentiation in SLE patients compared with controls and patients with atherosclerosis, thus suggesting a common pathogenic base between SLE and atherogenesis [174]. We were not able to retrieve studies specifically examining the role of macrophage accumulation and activation and promotion of atherosclerosis in AS or PsA, however, pathogenic similarities between atherosclerosis and psoriasis, involving monocyte/macrophage infiltration and secretion of chemokines and cytokines, could also stand for PsA [175].

\subsubsection{Pro-Inflammatory Cytokines}

Proinflammatory cytokines are involved in all stages of atherosclerosis and therefore are considered key mediators in the pathogenesis of CVD. From activation of the endothelium and recruitment of immune cells to monocyte differentiation, foam cell formation, plaque rupture, and thrombosis, cytokines orchestrate the whole inflammatory process; both the innate and adaptive immune response $[176,177]$.

Dyslipidemia is promoted by sustained inflammation as certain cytokines, namely TNFa and IL6, have been shown to influence lipid levels, shifting them towards an atherogenic profile [178]. Other cytokines, such as IFN- $\gamma$ and TNF- $\alpha$ can modulate the permeability of vascular endothelial cells to 
macromolecules such as LDL and activated endothelial cells release chemokines and other cytokines in order to recruit immune cells, particularly monocytes and T-lymphocytes, in the lesion [179].

Cytokines are also responsible for the differentiation of monocytes to macrophages in the arterial intima and the macrophage differentiation to phenotypes. T-helper-1 (Th1) cytokines such as IFN- $\gamma$ and IL-1 $\beta$ favor M1 phenotype, which produces pro-inflammatory cytokines such as IL-6, IL-12 and TNF- $\alpha$, whereas Th 2 cytokines such as IL- 4 and IL-13 are required for M2 phenotype, which produces anti-inflammatory cytokines such as IL-10 and TGF- $\beta$. TNF-a, IL-4, and IL-13 are also known to promote LDL oxidation by monocytes/macrophages and IFN- $\gamma$ stimulates macrophage foam cell formation by increasing the uptake of modified LDL and decreasing cholesterol efflux. A recent review highlighted the cellular and oxidative mechanisms of IL-6 signaling in the vasculature, including endothelial activation, vascular permeability, immune cell recruitment, endothelial dysfunction, as well as vascular hypertrophy and fibrosis $[180,181]$.

TL1A is another inflammatory cytokine and member of the TNF superfamily of ligands, whose impact on atherogenesis has recently been a topic of interest. TL1A, via binding to death-domain receptor 3 (DR3) expressed in lymphocytes, is important for T-cell costimulation and Th1 polarization, the induction of pro-inflammatory cytokines/chemokines, and also promotes macrophage foam cell formation [182,183]. Furthermore, various growth factors produced by macrophages, such as ECs and T-cells, control the migration and proliferation of smooth muscle cells and other pro-inflammatory cytokines, such as IFN- $\gamma$ and TNFa, affect plaque vulnerability by stimulating the apoptosis of macrophages and of smooth muscle cells. Finally, certain pro-inflammatory cytokines, such as TNF-a and IL-6, also suppress natural anticoagulant mechanisms, such as the protein C pathway, therefore favoring coagulation [178].

As in atherosclerosis, it is well known that aberrations in cytokine expression and signaling have pivotal pathogenetic roles in CIRD. In RA, many of the local and systemic manifestations appear to result from the production of a variety of cytokines within the inflamed synovium, particularly TNF- $\alpha$, IL-1 and IL-6 [184], and inhibition of these cytokines with biologic agents is currently a main therapeutic option for patients with RA. Interestingly, between the proinflammatory cytokines involved in the pathogenesis of RA, TNFa and IL6 are independently predictive of a subsequent CV event, suggesting a more direct effect of these cytokines on the endothelium [185]. The overexpression of these proinflammatory cytokinesin RA could be responsible for the accelerated CVD risk. Increased production of IFN $\gamma$ in RA, as a result of a significant amount of $\mathrm{CD} 4^{+} \mathrm{CD} 28^{-}$cells that promoteTh1cell activation, could also have a critical role in accelerated atherosclerosis [186,187].

Regarding TL1A, recent studies have demonstrated that this cytokine is overexpressed in synovial fluids and synovial tissue, as well as serum of rheumatoid factor (RF)-seropositive RA patients, and this expression is correlated with disease activity $[188,189]$. In addition, individual serum levels of TL1A correlated with the progression of carotid atheromatic plaque height and the formation of new plaques, indicating that the dysregulated TL1A induced signaling may be associated with risk for accelerated atherosclerosis in RA [190].

Finally, cytokine-induced metabolic effects could induce atherosclerosis by altering the classical CVD risk factors. Cytokines such as TNFa and IL-6 favor insulin resistance in RA patients, as well as a more atherogenic lipid profile $[83,103,191]$. This is amplified by the fact that anti-TNF treatment improves insulin resistance and increases the levels or atheroprotective HDL, however, it does not seem to ameliorate the overall atherogenic index in the long term, while anti-IL6 treatment seems to improve insulin resistance but increases levels of total cholesterols, LDL, and triglycerides [89,192].

The link between SLE pathogenesis and atheromatosis mainly concerns the innate immune system rather than T and B cells. More specifically, IFN- $\gamma$, which is well known to play a central role in SLE pathogenesis, is also implicated in the promotion of atherosclerosis, as the majority of pathogenic $\mathrm{T}$ cells are of the Th1 profile, producing high levels of IFN- $\gamma$. IFN- $\gamma$ activates monocytes/macrophages and dendritic cells, leading to the perpetuation of the pathogenic Th1 response that promotes smooth muscle cell proliferation. Moreover, type I interferons, that have also been postulated to play a central 
role in SLE pathogenesis [193], constitute a critical link between the two diseases. IFN- $\alpha$ increases the uptake of oxLDL and enhances foam cell formation and IFN- $\beta$ affect the adhesion and migration of leucocytes to plaques and promotes plaque rupture, possibly attributing the higher prevalence of $C V$ events in SLE to plaque instability $[176,194,195]$. As previously mentioned, TNFa and IL-6 have been shown to influence lipid levels in SLE, shifting them towards an atherogenic profile $[104,178,194]$.

Data on the pathogenic role of cytokines and atherosclerosis in AS and PsA is scarce. Among pro-inflammatory cytokines, TNF- $\alpha$ is a key pathogenic factor in AS and IL-17 and IL-23 in PsA. As in RA, TNFa is implicated in the pathogenesis of atherosclerosis and may also have a harmful effect on lipid profile in patients with AS. Regarding IL17 and IL23, data from different studies are contradictory, as IL-17 has been thought to be atheroprotective as well as proatherogenic. IL-17 seems to inhibit the development of Th1 cells by activation of IL-17 receptors. On the other hand, higher IL-17 expression in human carotid plaques was associated with a more stable phenotype. Apart from the direct effect on the vasculature, IL17 and IL-23 are known to be elevated in obese individuals and are implicated in the development of MetS, as they increase IR [21,196,197].

\section{What It All Means for Treatment of Patients with CIRD}

The therapeutic effect of different biologic and non-biologic antirheumatic drugs on CVD has been widely investigated in recent years. Firstly, antirheumatic therapies seem to differently affect classical CVD risk factors and MetS. In RA there is evidence from systematic reviews and large observational studies that MTX therapy may decrease CV morbidity and mortality [198]. The use of MTX is associated with a reduced chance of having MetS [87] but increases total cholesterol, LDL, HDL, and triglycerides in RA. However, these lipid increases are possibly due to the inflammatory-dampering effect and essentially reflect normalization of the lipid levels to those seen in the general population $[90,91]$ and therefore are not generally believed to increase $\mathrm{CV}$ risk. We should point out that the pathophysiologic mechanisms causing increased prevalence of MetS differ between rheumatic diseases. For example, in SLE, insulin resistance was not associated with IL-6 or TNFa levels as in RA, only with BMI and ESR [103], therefore it is possible that each condition requires a more customized management for prevention of CVD.

On the other hand, established therapies classically used for the management of traditional risk factors, such as statins or angiotensin-converting-enzyme inhibitors, could have a favorable impact on CIRD by bearing an anti-inflammatory effect. A recent review by Soulaidopoulos et al. reported evidence on the angioprotective, antioxidative and anti-inflammatory properties of statins and their efficacy in reducing RA-disease activity, supporting that RA patients should be screened via non-invasive methods for increased subclinical CVD—namely by cIMT evaluation—in order to receive lipid-lowering therapy when needed $[1,4,97]$.

Numerous studies have demonstrated that the use of biologic agents in CIRD blocking cytokines, such as TNF and IL6, can decelerate the atherogenic process and even improve endothelial function, arterial stiffness, or arterial wall hypertrophy. A recent meta-analysis focusing on the impact of TNFa inhibitors showed that TNF-a antagonist treatment induced a significant improvement in aortic PWV and Aix and therefore on CV risk [199]. The same stands for IL-6 receptor inhibition, as the use of the anti-IL-6 receptor antibody tocilizumab improved endothelial dysfunction and aortic stiffness in patients with RA [200]. A review by Tam et al. concluded that the use of biologic agents in RA probably is effective in preventing the progression of subclinical atherosclerosis and improving arterial stiffness, although results from different studies are contradictory, and it cannot be clear whether this effect goes beyond that of controlling inflammation irrespective of the disease modification strategy by which this is achieved [201]. Similarly, we have shown that effective disease control may abrogate any RA-specific effect on the progression of atherosclerosis, irrespective of treatment modalities [37].

In a large British cohort, patients with RA receiving TNF inhibitors have a decreased risk of MI compared with patients receiving cDMARDs [202]. Finally, a meta-analysis examining the association between CV events and antirheumatic drugs concluded that TNFa inhibitors and MTX are both 
associated with a reduced risk of CV events [203]. Data on other therapies is more limited. A recent review by Ketelhuth et al. found evidence from preclinical and clinical studies on the therapeutic effect of various immunomodulatory therapies on CVD, including IFN $\gamma$ and IL17 [204]. Koga et al. argued that postnatal blocking of IFN- $\gamma$ function by gene transfer of a soluble mutant of IFN- $\gamma$ receptor in adult mice prevented the progression of established plaques that remodeled toward a more stable and less inflammatory phenotype [205], thus implying that a IFN- $\gamma$ blockade could reduce CV events. Importantly, a recent secondary CVD prevention multicenter placebo-controlled study revealed that anti-inflammatory therapy targeting the interleukin- $1 \beta$ innate immunity pathway led to a significantly lower rate of recurrent CV events than placebo, independent of lipid-level lowering [206]. Such a claim paves the way for the use of biologic agents specifically for the management of CVD.

The use of biologic agents in the majority of studies was not associated with significantly increased infections compared to the placebo-treated group. However, the potential risk of the development of opportunistic infections due to immunosuppression should be noted, and the expected benefit from any biologic treatment should be considered in the context of this risk.

Recently, the chemoattractant chemerin, which is considered an independent predictor of cardiovascular disease risk, was associated with endothelial activation and atherosclerosis in RA, and the blockade of TNFa and IL-6 seems to reduce chemerin concentrations in RA patients [207,208]. Similarly to classical risk factors, there is heterogeneity with respect to autoimmune-inflammatory risk factors between rheumatic diseases. Cytokines, such as TNF- $\alpha$ and immune complexes are primarily involved in arthritides, such as RA, AS and PsA, as well as in SLE. On the other hand, interferons and autoantibodies are rather involved in SLE-associated vascular conditions. IL17/IL23 are more involved in the pathogenesis of PsA. Therefore, the therapeutic management of CVD in each condition should be customized.

\section{Practical Implications}

The increased morbidity and mortality associated with CVD in CIRD designated the need for better understanding the common underlying pathogenic mechanisms. The common background of these conditions is inflammation and the dysregulation of the immune system, and numerous studies in recent years have focused on unraveling the exact process and molecules behind this interaction. Even though some of the studies performed present methological issues and therefore reach questionable and contentious results, the overall conclusion of an association between CIRD and accelerated atherosclerosis is definite. This way we could be able to effectively manage both atherosclerosis and CIRD with therapies targeting molecules and specific pathways that are implicated in the shared pathogenesis.

To ameliorate the impact of CVD in the morbidity and mortality of CIRD patients, it is important to promptly recognize and effectively manage classical modifiable CVD risk factors, as studies have shown that they are under-diagnosed and under-treated despite more close and regular monitoring $[78,79]$. As outlined above, inflammation alters the metabolic profile in these patients and effective treatment normalizes this metabolic state, however, anti-hypertensive treatment and especially lipid-lowering therapy should be initiated in each patient in such need early in the disease course. Since the decision to start a drug treatment of high blood pressure and lipids is based on total CV risk levels as assessed by international algorithms (e.g., the EU score), it is expected that the multiplication of these scores in (e.g., RA) will have a substantial impact on the management of $\mathrm{CV}$ risk factor in RA. Moreover, we should always take into account before initiation of therapies the demographic characteristics of each CIRD and each patient individually. For example, the age of disease onset for RA patients is usually greater than SLE or AS patients and AS patients are usually men, thus adding to the already increased CV burden. Interestingly, as previously mentioned, younger SLE women present higher relative risk of CVD compared to the general population than SLE women of more than 60 years of age. Lastly and more importantly, disease duration, apart from disease activity, 
seems to be an important factor determining CVD. This is more documented for RA [1,39] and several studies indicate that it applies for other CIRD.

We should point out that despite all the advances and research on the management of CVD in CIRD, studies still denote an increased prevalence of CV events and mortality in rheumatic diseases compared to the general population. More specifically, although the diagnosis and treatment of SLE has significantly improved and deaths due to lupus manifestations have decreased, those due to CVD in SLE have not; CVD remains a leading cause of death [209,210]. In PsA, two studies from the same cohort but from two different time periods demonstrated an increased overall mortality risk over nearly four decades of follow-up, but the mortality risk declined over time [211,212]. Finally, a recent meta-analysis by Mathieu et al. found a reduction in the prevalence and risk of MI and stroke in AS compared with a previous meta-analysis by the same researchers $[18,109,213]$ probably attributable to improvements in the control of cardiovascular risk in AS.

The possible role of cytokine measurement in the diagnosis and prevention of $\mathrm{CV}$ events should be also considered. Wainstein et al. showed that IL-6 levels are predictive of significant coronary artery disease in patients referred for coronary angiography and Lin et al. concluded that IL-6 demonstrated a notable prognostic value for predicting cardiovascular mortality $[214,215]$.

To conclude, CIRD and atherosclerosis share common pathogenic mechanisms and this raises the possibility of a common therapeutic strategy. Apart from the adequate management of cardiovascular comorbidities, which still remains insufficient, therapeutic options could include the blockade of proiflammatory cytokines implicated in both diseases. Whether the low relative risks of CVD in CIRD justify further research in the biomedical field to broaden therapeutic options remains open to debate. Future studies should focus on other potential targets implicated in atherosclerosis pathogenesis; i.e., the NLRP3 inflammasome or specific or multiple chemokines.

Author Contributions: All authors meet the authorship criteria. A.A. and A.D.P. independently performed a literature search of published studies. All authors contributed to the collection and subsequent interpretation of data. A.A. and P.P.S. drafted the manuscript and A.D.P. and G.D.K. revised the manuscript and all authors approved the final version.

Conflicts of Interest: The authors declare no conflicts of interest.

$\begin{array}{ll}\text { Abbreviation } & \\ \text { ACPA } & \text { Anti-citrullinated protein/peptide antibodies } \\ \text { Aix } & \text { Augmentation index } \\ \text { APS } & \text { Antiphospholipid syndrome } \\ \text { AS } & \text { Ankylosing spondylitis } \\ \text { ASDAS } & \text { Ankylosing Spondylitis Disease Activity Score } \\ \text { BASDAI } & \text { Bath Ankylosing Spondylitis Disease Activity Index } \\ \text { BMI } & \text { Body mass index } \\ \text { cDMARDs } & \text { Conventional disease modifying antirheumatic drugs } \\ \text { CHD } & \text { Coronary heart disease } \\ \text { cIMT } & \text { Carotid intima-media thickness } \\ \text { CIRD } & \text { Chronic inflammatory rheumatic diseases } \\ \text { CRP } & \text { C-reactive protein } \\ \text { CV } & \text { Cardiovascular } \\ \text { CVD } & \text { Cardiovascular disease } \\ \text { DAMPs } & \text { Damage-associated molecular patterns } \\ \text { DM } & \text { Diabetes Mellitus } \\ \text { DR3 } & \text { Death-domain receptor 3 } \\ \text { ds-DNA } & \text { Double stranded deoxyribonucleic acid } \\ \text { e.g., } & \text { For example } \\ \end{array}$




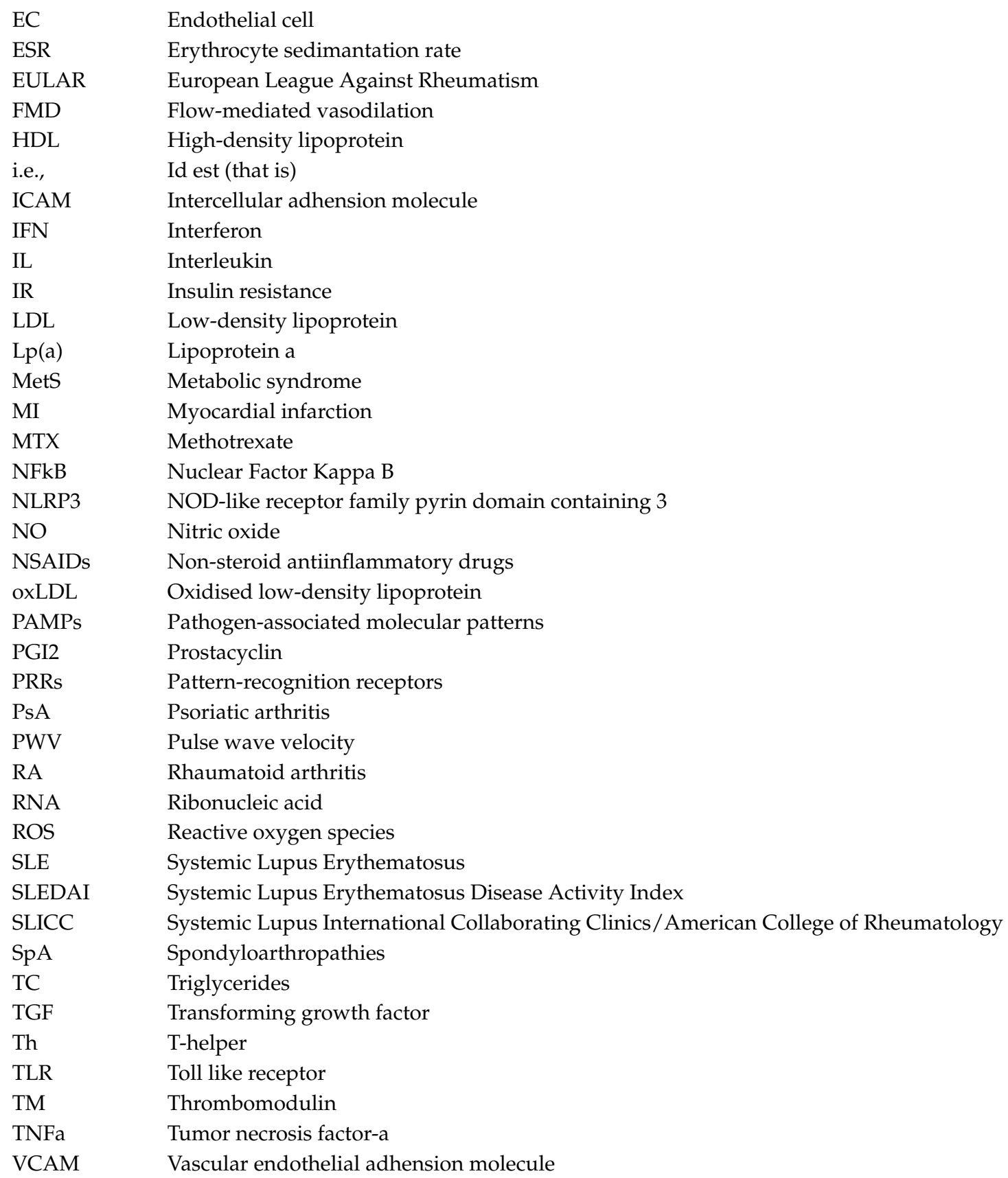

\section{References}

1. Peters, M.J.; Symmons, D.P.M.; McCarey, D.; Dijkmans, B.A.C.; Nicola, P.; Kvien, T.K.; McInnes, I.B.; Haentzschel, H.; Gonzalez-Gay, M.A.; Provan, S.; et al. EULAR evidence-based recommendations for cardiovascular risk management in patients with rheumatoid arthritis and other forms of inflammatory arthritis. Ann. Rheum. Dis. 2010, 69, 325-331. [CrossRef] [PubMed]

2. Aviña-Zubieta, J.A.; Choi, H.K.; Sadatsafavi, M.; Etminan, M.; Esdaile, J.M.; Lacaille, D. Risk of cardiovascular mortality in patients with rheumatoid arthritis: A meta-analysis of observational studies. Arthritis Care Res. 2008, 59, 1690-1697. [CrossRef] [PubMed]

3. Dadoun, S.; Zeboulon-Ktorza, N.; Combescure, C.; Elhai, M.; Rozenberg, S.; Gossec, L.; Fautrel, B. Mortality in rheumatoid arthritis over the last fifty years: Systematic review and meta-analysis. Jt. Bone Spine 2013, 80, 29-33. [CrossRef] [PubMed] 
4. Agca, R.; Heslinga, S.C.; Rollefstad, S.; Heslinga, M.; McInnes, I.B.; Peters, M.J.L.; Kvien, T.K.; Dougados, M.; Radner, H.; Atzeni, F.; et al. Nurmohamed, EULAR recommendations for cardiovascular disease risk management in patients with rheumatoid arthritis and other forms of inflammatory joint disorders: 2015/2016 update. Ann. Rheum. Dis. 2017, 76, 17-28. [CrossRef] [PubMed]

5. Liao, K.P.; Solomon, D.H. Traditional cardiovascular risk factors, inflammation and cardiovascular risk in rheumatoid arthritis. Rheumatology 2013, 52, 45-52. [CrossRef] [PubMed]

6. Solomon, D.H.; Kremer, J.; Curtis, J.R.; Hochberg, M.C.; Reed, G.; Tsao, P.; Farkouh, M.E.; Setoguchi, S.; Greenberg, J.D. Explaining the cardiovascular risk associated with rheumatoid arthritis: Traditional risk factors versus markers of rheumatoid arthritis severity. Ann. Rheum. Dis. 2010, 69, 1920-1925. [CrossRef] [PubMed]

7. Sfikakis, P.P.; Bournia, V.-K.; Kitas, G. Do non-steroidal anti-inflammatory drugs increase or decrease cardiovascular risk in patients with rheumatoid arthritis? Clin. Exp. Rheumatol. 2014, 73, 1515-1521.

8. Van Halm, V.P.; Peters, M.J.L.; Voskuyl, A.E.; Boers, M.; Lems, W.F.; Visser, M.; Stehouwer, C.D.A.; Spijkerman, A.M.W.; Dekker, J.M.; Nijpels, G.; et al. Rheumatoid arthritis versus diabetes as a risk factor for cardiovascular disease: A cross-sectional study, the CARRE Investigation. Ann. Rheum. Dis. 2009, 68, 1395-1400. [CrossRef] [PubMed]

9. Stamatelopoulos, K.S.; Kitas, G.D.; Papamichael, C.M.; Chryssohoou, E.; Kyrkou, K.; Georgiopoulos, G.; Protogerou, A.; Panoulas, V.F.; Sandoo, A.; Tentolouris, N.; et al. Atherosclerosis in Rheumatoid Arthritis Versus Diabetes: A Comparative Study. Arterioscler. Thromb. Vasc. Biol. 2009, 29, 1702-1708. [CrossRef] [PubMed]

10. Lindhardsen, J.; Ahlehoff, O.; Gislason, G.H.; Madsen, O.R.; Olesen, J.B.; Torp-Pedersen, C.; Hansen, P.R. The risk of myocardial infarction in rheumatoid arthritis and diabetes mellitus: A Danish nationwide cohort study. Ann. Rheum. Dis. 2011, 70, 929-934. [CrossRef] [PubMed]

11. Esdaile, J.M.; Abrahamowicz, M.; Grodzicky, T.; Li, Y.; Panaritis, C.; Berger, R.D.; Côté, R.; Grover, S.A.; Fortin, P.R.; Clarke, A.E.; et al. Traditional Framingham risk factors fail to fully account for accelerated atherosclerosis in systemic lupus erythematosus. Arthritis Rheumatol. 2001, 44, 2331-2337. [CrossRef]

12. Bartels, C.M.; Buhr, K.A.; Goldberg, J.W.; Bell, C.L.; Visekruna, M.; Nekkanti, S.; Greenlee, R.T. Mortality and Cardiovascular Burden of Systemic Lupus Erythematosus in a US Population-based Cohort. J. Rheumatol. 2014, 41, 680-687. [CrossRef] [PubMed]

13. Schoenfeld, S.R.; Kasturi, S.; Costenbader, K.H. The epidemiology of atherosclerotic cardiovascular disease among patients with SLE: A systematic review. Semin. Arthritis Rheum. 2013, 43, 77-95. [CrossRef] [PubMed]

14. Wu, G.C.; Liu, H.R.; Leng, R.X.; Li, X.P.; Li, X.M.; Pan, H.F.; Ye, D.Q. Subclinical atherosclerosis in patients with systemic lupus erythematosus: A systemic review and meta-analysis. Autoimmun. Rev. 2016, 15, $22-37$. [CrossRef] [PubMed]

15. Tektonidou, M.G.; Kravvariti, E.; Konstantonis, G.; Tentolouris, N.; Sfikakis, P.P.; Protogerou, A. Subclinical atherosclerosis in Systemic Lupus Erythematosus: Comparable risk with Diabetes Mellitus and Rheumatoid Arthritis. Autoimmun. Rev. 2017, 16, 308-312. [CrossRef] [PubMed]

16. Henrot, P.; Foret, J.; Barnetche, T.; Lazaro, E.; Duffau, P.; Seneschal, J.; Schaeverbeke, T.; Truchetet, M.E.; Richez, C. Assessment of subclinical atherosclerosis in systemic lupus erythematosus: A systematic review and meta-analysis. Jt. Bone Spine 2018, 85, 155-163. [CrossRef] [PubMed]

17. Schieir, O.; Tosevski, C.; Glazier, R.H.; Hogg-Johnson, S.; Badley, E.M. Incident myocardial infarction associated with major types of arthritis in the general population: A systematic review and meta-analysis. Ann. Rheum. Dis. 2017, 76, 1396-1404. [CrossRef] [PubMed]

18. Mathieu, S.; Soubrier, M. Cardiovascular events in ankylosing spondylitis: A 2018 meta-analysis. Ann. Rheum. Dis. 2018. [CrossRef] [PubMed]

19. Papagoras, C.; Markatseli, T.E.; Saougou, I.; Alamanos, Y.; Zikou, A.K.; Voulgari, P.V.; Kiortsis, D.N.; Drosos, A.A. Cardiovascular risk profile in patients with spondyloarthritis. Jt. Bone Spine 2014, 81, 57-63. [CrossRef] [PubMed]

20. Han, C.; Robinson, D.W.; Hackett, M.V.; Paramore, L.C.; Fraeman, K.H.; Bala, M.V. Cardiovascular disease and risk factors in patients with rheumatoid arthritis, psoriatic arthritis, and ankylosing spondylitis. J. Rheumatol. 2006, 33, 2167-2172. [PubMed]

21. Puig, L. Cardiometabolic Comorbidities in Psoriasis and Psoriatic Arthritis. Int. J. Mol. Sci. 2017, 19, 58. [CrossRef] [PubMed] 
22. Bournia, V.-K.; Kitas, G.; Protogerou, A.D.; Sfikakis, P.P. Impact of non-steroidal anti-inflammatory drugs on cardiovascular risk: Is it the same in osteoarthritis and rheumatoid arthritis? Mod. Rheumatol. 2017, 27, 559-569. [CrossRef] [PubMed]

23. Arida, A.; Protogerou, A.D.; Konstantonis, G.; Konsta, M.; Delicha, E.M.; Kitas, G.D.; Sfikakis, P.P. Subclinical Atherosclerosis Is Not Accelerated in Patients with Ankylosing Spondylitis with Low Disease Activity: New Data and Metaanalysis of Published Studies. J. Rheumatol. 2015, 42, 2098-2105. [CrossRef] [PubMed]

24. Bakland, G.; Gran, J.T.; Nossent, J.C. Increased mortality in ankylosing spondylitis is related to disease activity. Ann. Rheum. Dis. 2011, 70, 1921-1925. [CrossRef] [PubMed]

25. Ridker, P.M.; Hennekens, C.H.; Buring, J.E.; Rifai, N. C-Reactive Protein and Other Markers of Inflammation in the Prediction of Cardiovascular Disease in Women. N. Engl. J. Med. 2000, 342, 836-843. [CrossRef] [PubMed]

26. Kaptoge, S.; Thompson, S.G.; Danesh, J. Emerging Risk Factors Collaboration, C-Reactive Protein, Fibrinogen, and Cardiovascular Risk. N. Engl. J. Med. 2013, 368, 84-86. [CrossRef]

27. Ridker, P.M.; Luscher, T.F. Anti-inflammatory therapies for cardiovascular disease. Eur. Heart J. 2014, 35, 1782-1791. [CrossRef] [PubMed]

28. Wu, M.Y.; Li, C.J.; Hou, M.F.; Chu, P.Y. New Insights into the Role of Inflammation in the Pathogenesis of Atherosclerosis. Int. J. Mol. Sci. 2017, 18, 2034. [CrossRef] [PubMed]

29. Peters, M.J.; Van Halm, V.P.; Voskuyl, A.E.; Smulders, Y.M.; Boers, M.; Lems, W.F.; Visser, M.; Stehouwer, C.D.; Dekker, J.M.; Nijpels, G.; et al. Does rheumatoid arthritis equal diabetes mellitus as an independent risk factor for cardiovascular disease? A prospective study. Arthritis Care Res. 2009, 61, 1571-1579. [CrossRef] [PubMed]

30. Lévy, L.; Fautrel, B.; Barnetche, T.; Schaeverbeke, T. Incidence and risk of fatal myocardial infarction and stroke events in rheumatoid arthritis patients. A systematic review of the literature. Clin. Exp. Rheumatol. 2008, 26, 673-679. [PubMed]

31. Meune, C.; Touzé, E.; Trinquart, L.; Allanore, Y. High risk of clinical cardiovascular events in rheumatoid arthritis: Levels of associations of myocardial infarction and stroke through a systematic review and meta-analysis. Arch. Cardiovasc. Dis. 2010, 103, 253-261. [CrossRef] [PubMed]

32. Mok, C.C.; Kwok, C.L.; Ho, L.Y.; Chan, P.T.; Yip, S.F. Life expectancy, standardized mortality ratios, and causes of death in six rheumatic diseases in Hong Kong, China. Arthritis Rheumatol. 2011, 63, 1182-1189. [CrossRef] [PubMed]

33. Exarchou, S.; Lie, E.; Lindström, U.; Askling, J.; Forsblad-d'Elia, H.; Turesson, C.; Kristensen, L.E.; Jacobsson, L.T. Mortality in ankylosing spondylitis: Results from a nationwide population-based study. Ann. Rheum. Dis. 2016, 75, 1466-1472. [CrossRef] [PubMed]

34. Haroon, N.N.; Paterson, J.M.; Li, P.; Inman, R.D.; Haroon, N. Patients with Ankylosing Spondylitis Have Increased Cardiovascular and Cerebrovascular Mortality. Ann. Intern. Med. 2015, 163, 409-416. [CrossRef] [PubMed]

35. Jamnitski, A.; Visman, I.M.; Peters, M.J.L.; Boers, M.; Dijkmans, B.A.C.; Nurmohamed, M.T. Prevalence of cardiovascular diseases in psoriatic arthritis resembles that of rheumatoid arthritis. Ann. Rheum. Dis. 2011, 70, 875-876. [CrossRef] [PubMed]

36. Nurmohamed, M.T.; van der Horst-Bruinsma, I.; Maksymowych, W.P. Cardiovascular and Cerebrovascular Diseases in Ankylosing Spondylitis: Current Insights. Curr. Rheumatol. Rep. 2012, 14, 415-421. [CrossRef] [PubMed]

37. Gladman, D.D.; Ang, M.; Su, L.; Tom, B.D.; Schentag, C.T.; Farewell, V.T. Cardiovascular morbidity in psoriatic arthritis. Ann. Rheum. Dis. 2009, 68, 1131-1135. [CrossRef] [PubMed]

38. Ambrosino, P.; Lupoli, R.; Di Minno, A.; Tasso, M.; Peluso, R.; Di Minno, M.N.D. Subclinical atherosclerosis in patients with rheumatoid arthritis. Thromb. Haemost. 2015, 113, 916-930. [CrossRef] [PubMed]

39. Di Minno, M.N.D.; Ambrosino, P.; Lupoli, R.; Di Minno, A.; Tasso, M.; Peluso, R.; Tremoli, E. Cardiovascular risk markers in patients with psoriatic arthritis: A meta-analysis of literature studies. Ann. Med. 2015, 47, 346-353. [CrossRef] [PubMed]

40. Ambrosino, P.; Tasso, M.; Lupoli, R.; Di Minno, A.; Baldassarre, D.; Tremoli, E.; Di Minno, M.N.D. Non-invasive assessment of arterial stiffness in patients with rheumatoid arthritis: A systematic review and meta-analysis of literature studies. Ann. Med. 2015, 47, 457-467. [CrossRef] [PubMed] 
41. Sacre, K.; Escoubet, B.; Pasquet, B.; Chauveheid, M.P.; Zennaro, M.C.; Tubach, F.; Papo, T. Increased arterial stiffness in systemic lupus erythematosus (SLE) patients at low risk for cardiovascular disease: A cross-sectional controlled study. PLoS ONE 2014, 9, e94511. [CrossRef] [PubMed]

42. Shang, Q.; Tam, L.; Li, E.; Yip, G.; Yu, C. Increased arterial stiffness correlated with disease activity in systemic lupus erythematosus. Lupus 2008, 17, 1096-1102. [CrossRef] [PubMed]

43. Cypiene, A.; Kovaite, M.; Venalis, A.; Dadoniene, J.; Rugiene, R.; Petrulioniene, Z.; Ryliskyte, L.; Laucevicius, A. Arterial wall dysfunction in systemic lupus erythematosus. Lupus 2009, 18, 522-529. [CrossRef] [PubMed]

44. Capkin, E.; Kiris, A.; Karkucak, M.; Durmus, I.; Gokmen, F.; Cansu, A.; Tosun, M.; Ayar, A. Investigation of effects of different treatment modalities on structural and functional vessel wall properties in patients with ankylosing spondylitis. Jt. Bone Spine 2011, 78, 378-382. [CrossRef] [PubMed]

45. Bodnár, N.; Kerekes, G.; Seres, I.; Paragh, G.; Kappelmayer, J.; Némethné, Z.G.; Szegedi, G.; Shoenfeld, Y.; Sipka, S.; Soltész, P.; et al. Assessment of Subclinical Vascular Disease Associated with Ankylosing Spondylitis. J. Rheumatol. 2011, 38, 723-729. [CrossRef] [PubMed]

46. Costa, L.; Caso, F.; D’Elia, L.; Atteno, M.; Peluso, R.; Del Puente, A.; Strazzullo, P.; Scarpa, R. Psoriatic arthritis is associated with increased arterial stiffness in the absence of known cardiovascular risk factors: A case control study. Clin. Rheumatol. 2012, 31, 711-715. [CrossRef] [PubMed]

47. Shen, J.; Shang, Q.; Li, E.K.; Leung, Y.Y.; Kun, E.W.; Kwok, L.W.; Li, M.; Li, T.K.; Zhu, T.Y.; Yu, C.M.; et al. Cumulative inflammatory burden is independently associated with increased arterial stiffness in patients with psoriatic arthritis: A prospective study. Arthritis Res. Ther. 2015, 17, 75. [CrossRef] [PubMed]

48. Di Minno, M.N.D.; Ambrosino, P.; Lupoli, R.; Di Minno, A.; Tasso, M.; Peluso, R.; Tremoli, E. Clinical assessment of endothelial function in patients with rheumatoid arthritis: A meta-analysis of literature studies. Eur. J. Intern. Med. 2015, 26, 835-842. [CrossRef] [PubMed]

49. Xu, S.Z.; Wang, P.; Guan, S.Y.; Li, H.M.; Leng, R.X.; Pan, H.F.; Ye, D.Q. Decreased flow-mediated dilatation in patients with rheumatoid arthritis: A meta-analysis. Postgrad. Med. J. 2017, 93, 260-265. [CrossRef] [PubMed]

50. Sabio, J.M.; Vargas-Hitos, J.; Zamora-Pasadas, M.; Mediavilla, J.D.; Navarrete, N.; Ramirez, Á.; Hidalgo-Tenorio, C.; Jáimez, L.; Martín, J.; Jiménez-Alonso, J. Metabolic syndrome is associated with increased arterial stiffness and biomarkers of subclinical atherosclerosis in patients with systemic lupus erythematosus. J. Rheumatol. 2009, 36, 2204-2211. [CrossRef] [PubMed]

51. Valero-Gonzalez, S.; Castejon, R.; Jimenez-Ortiz, C.; Rosado, S.; Tutor-Ureta, P.; Vargas, J.A.; Yebra-Bango, M. Increased arterial stiffness is independently associated with metabolic syndrome and damage index in systemic lupus erythematosus patients. Scand. J. Rheumatol. 2014, 43, 54-58. [CrossRef] [PubMed]

52. Protogerou, A.; Zampeli, E.; Tentolouris, N.; Makrilakis, K.; Kitas, G.; Sfikakis, P.P. Subclinical femoral atheromatosis in rheumatoid arthritis: Comparable prevalence to diabetes mellitus in a case-control study. Ann. Rheum. Dis. 2012, 71, 1534-1536. [CrossRef] [PubMed]

53. Del Rincón, I.; Polak, J.F.; O’leary, D.H.; Battafarano, D.F.; Erikson, J.M.; Restrepo, J.F.; Molina, E.; Escalante, A. Systemic inflammation and cardiovascular risk factors predict rapid progression of atherosclerosis in rheumatoid arthritis. Ann. Rheum. Dis. 2015, 74, 1118-1123. [CrossRef] [PubMed]

54. Myasoedova, E.; Chandran, A.; Ilhan, B.; Major, B.T.; Michet, C.J.; Matteson, E.L.; Crowson, C.S. The role of rheumatoid arthritis (RA) flare and cumulative burden of RA severity in the risk of cardiovascular disease. Ann. Rheum. Dis. 2016, 75, 560-565. [CrossRef] [PubMed]

55. Arida, A.; Protogerou, A.D.; Konstantonis, G.; Fragiadaki, K.; Kitas, G.D.; Sfikakis, P.P. Atherosclerosis is not accelerated in rheumatoid arthritis of low activity or remission, regardless of antirheumatic treatment modalities. Rheumatology 2017, 56, 934-939. [CrossRef] [PubMed]

56. Kitas, G.D.; Gabriel, S.E. Cardiovascular disease in rheumatoid arthritis: State of the art and future perspectives. Ann. Rheum. Dis. 2011, 70, 8-14. [CrossRef] [PubMed]

57. Arida, A.; Zampeli, E.; Konstantonis, G.; Fragiadaki, K.; Kitas, G.D.; Protogerou, A.D.; Sfikakis, P.P. Rheumatoid arthritis is sufficient to cause atheromatosis but not arterial stiffness or hypertrophy in the absence of classical cardiovascular risk factors. Clin. Rheumatol. 2015, 34, 853-859. [CrossRef] [PubMed]

58. Zhang, J.; Chen, L.; Delzell, E.; Muntner, P.; Hillegass, W.B.; Safford, M.M.; Millan, I.Y.N.; Crowson, C.S.; Curtis, J.R. The association between inflammatory markers, serum lipids and the risk of cardiovascular events in patients with rheumatoid arthritis. Ann. Rheum. Dis. 2014, 73, 1301-1308. [CrossRef] [PubMed] 
59. Bernatsky, S.; Boivin, J.F.; Joseph, L.; Manzi, S.; Ginzler, E.; Gladman, D.D.; Urowitz, M.; Fortin, P.R.; Petri, M.; Barr, S.; et al. Mortality in systemic lupus erythematosus. Arthritis Rheumatol. 2006, 54, 2550-2557. [CrossRef] [PubMed]

60. Tektonidou, M.G.; Wang, Z.; Ward, M.M. Brief Report: Trends in Hospitalizations Due to Acute Coronary Syndromes and Stroke in Patients with Systemic Lupus Erythematosus, 1996 to 2012. Arthritis Rheumatol. 2016, 68, 2680-2685. [CrossRef] [PubMed]

61. Ghosh, P.; Kumar, A.; Kumar, S.; Aggarwal, A.; Sinha, N.; Misra, R. Subclinical atherosclerosis and endothelial dysfunction in young South-Asian patients with systemic lupus erythematosus. Clin. Rheumatol. 2009, 28, 1259-1265. [CrossRef] [PubMed]

62. Kiss, E.; Soltesz, P.; Der, H.; Kocsis, Z.; Tarr, T.; Bhattoa, H.; Shoenfeld, Y.; Szegedi, G. Reduced flow-mediated vasodilation as a marker for cardiovascular complications in lupus patients. J. Autoimmun. 2006, 27, 211-217. [CrossRef] [PubMed]

63. Selzer, F.; Sutton-Tyrrell, K.; Fitzgerald, S.; Tracy, R.; Kuller, L.; Manzi, S. Vascular stiffness in women with systemic lupus erythematosus. Hypertension 2001, 37, 1075-1082. [CrossRef] [PubMed]

64. Battista, F.; Pucci, G.; Bocci, E.B.; Anastasio, F.; Crapa, M.; Sanesi, L.; Gerli, R.; Schillaci, G. 2B.09: Arterial stiffness and disease-related organ damage in systemic lupus erythematosus. J. Hypertens. 2015, 33 , e24. [CrossRef] [PubMed]

65. Chou, C.H.; Lin, M.C.; Peng, C.L.; Wu, Y.C.; Sung, F.C.; Kao, C.H.; Liu, S.H. A nationwide population-based retrospective cohort study: Increased risk of acute coronary syndrome in patients with ankylosing spondylitis. Scand. J. Rheumatol. 2014, 43, 132-136. [CrossRef] [PubMed]

66. Keller, J.J.; Hsu, J.L.; Lin, S.M.; Chou, C.C.; Wang, L.H.; Wang, J.; Bai, C.H.; Chiou, H.Y. Increased risk of stroke among patients with ankylosing spondylitis: A population-based matched-cohort study. Rheumatol. Int. 2014, 34, 255-263. [CrossRef] [PubMed]

67. Demiralp, E.; Kardesoglu, E.; Kiralp, M.Z.; Cebeci, B.S.; Keskin, İ.; Ozmen, N.; Dursun, H. Aortic elasticity in patients with ankylosing spondylitis. Acta Cardiol. 2004, 59, 630-634. [CrossRef] [PubMed]

68. Berg, I.J.; Semb, A.G.; van der Heijde, D.; Kvien, T.K.; Olsen, I.C.; Dagfinrud, H.; Provan, S.A. CRP and ASDAS are associated with future elevated arterial stiffness, a risk marker of cardiovascular disease, in patients with ankylosing spondylitis: Results after 5-year follow-up. Ann. Rheum. Dis. 2015, 74, 1562-1566. [CrossRef] [PubMed]

69. Di Minno, M.N.D.; Iervolino, S.; Peluso, R.; Scarpa, R.; Di Minno, G. CaRRDs Study Group. Carotid Intima-Media Thickness in Psoriatic Arthritis: Differences between Tumor Necrosis Factor-Blockers and Traditional Disease-Modifying Antirheumatic Drugs. Arterioscler. Thromb. Vasc. Biol. 2011, 31, 705-712. [CrossRef] [PubMed]

70. Gonzalez-Juanatey, C.; Llorca, J.; Miranda-Filloy, J.A.; Amigo-Diaz, E.; Testa, A.; Garcia-Porrua, C.; Martin, J.; Gonzalez-Gay, M.A. Endothelial dysfunction in psoriatic arthritis patients without clinically evident cardiovascular disease or classic atherosclerosis risk factors. Arthritis Care Res. 2007, 57, 287-293. [CrossRef] [PubMed]

71. Gonzalez-juanatey, C.; Llorca, J.; Amigo-Diaz, E.; Dierssen, T.; Martin, J.; Gonzalez-Gay, M.A. High prevalence of subclinical atherosclerosis in psoriatic arthritis patients without clinically evident cardiovascular disease or classic atherosclerosis risk factors. Arthritis Care Res. 2007, 57, 1074-1080. [CrossRef] [PubMed]

72. Odegaard, J.I.; Chawla, A. Pleiotropic Actions of Insulin Resistance and Inflammation in Metabolic Homeostasis. Science 2013, 339, 172-177. [CrossRef] [PubMed]

73. Baghdadi, L.R.; Woodman, R.J.; Shanahan, E.M.; Mangoni, A.A. The impact of traditional cardiovascular risk factors on cardiovascular outcomes in patients with rheumatoid arthritis: A systematic review and meta-analysis. PLoS ONE 2015, 10, e0117952. [CrossRef] [PubMed]

74. Chung, C.P.; Giles, J.T.; Petri, M.; Szklo, M.; Post, W.; Blumenthal, R.S.; Gelber, A.C.; Ouyang, P.; Jenny, N.S.; Bathon, J.M. Prevalence of Traditional Modifiable Cardiovascular Risk Factors in Patients with Rheumatoid Arthritis: Comparison with Control Subjects from the Multi-Ethnic Study of Atherosclerosis. Semin. Arthritis Rheum. 2012, 41, 535-544. [CrossRef] [PubMed] 
75. Stavropoulos-Kalinoglou, A.; Metsios, G.S.; Panoulas, V.F.; Douglas, K.M.; Nevill, A.M.; Jamurtas, A.Z.; Kita, M.; Koutedakis, Y.; Kitas, G.D. Associations of obesity with modifiable risk factors for the development of cardiovascular disease in patients with rheumatoid arthritis. Ann. Rheum. Dis. 2009, 68, 242-245. [CrossRef] [PubMed]

76. Panoulas, V.F.; Douglas, K.M.; Milionis, H.J.; Stavropoulos-Kalinglou, A.; Nightingale, P.; Kita, M.D.; Tselios, A.L.; Metsios, G.S.; Elisaf, M.S.; Kitas, G.D. Prevalence and associations of hypertension and its control in patients with rheumatoid arthritis. Rheumatology 2007, 46, 1477-1482. [CrossRef] [PubMed]

77. Panoulas, V.F.; Metsios, G.S.; Pace, A.V.; John, H.; Treharne, G.J.; Banks, M.J.; Kitas, G.D. Hypertension in rheumatoid arthritis. Rheumatology 2008, 47, 1286-1298. [CrossRef] [PubMed]

78. Protogerou, A.D.; Panagiotakos, D.B.; Zampeli, E.; Argyris, A.A.; Arida, K.; Konstantonis, G.D.; Pitsavos, C.; Kitas, G.D.; Sfikakis, P.P. Arterial hypertension assessed "out-of-office" in a contemporary cohort of rheumatoid arthritis patients free of cardiovascular disease is characterized by high prevalence, low awareness, poor control and increased vascular damage-associated "white coat" phenomenon. Arthritis Res. Ther. 2013, 15, R142. [CrossRef] [PubMed]

79. Bartels, C.M.; Johnson, H.; Voelker, K.; Thorpe, C.; McBride, P.; Jacobs, E.A.; Pandhi, N.; Smith, M. Impact of Rheumatoid Arthritis on Receiving a Diagnosis of Hypertension Among Patients With Regular Primary Care. Arthritis Care Res. 2014, 66, 1281-1288. [CrossRef] [PubMed]

80. Chung, C.P.; Oeser, A.; Solus, J.F.; Avalos, I.; Gebretsadik, T.; Shintani, A.; Raggi, P.; Sokka, T.; Pincus, T.; Stein, C.M. Prevalence of the metabolic syndrome is increased in rheumatoid arthritis and is associated with coronary atherosclerosis. Atherosclerosis 2008, 196, 756-763. [CrossRef] [PubMed]

81. Dessein, P.H.; Tobias, M.; Veller, M.G. Metabolic syndrome and subclinical atherosclerosis in rheumatoid arthritis. J. Rheumatol. 2006, 33, 2425-2432. [PubMed]

82. Rostom, S.; Mengat, M.; Lahlou, R.; Hari, A.; Bahiri, R.; Hajjaj-Hassouni, N. Metabolic syndrome in rheumatoid arthritis: Case control study. BMC Musculoskelet. Disord. 2013, 14, 147. [CrossRef] [PubMed]

83. Rask-Madsen, C.; Domínguez, H.; Ihlemann, N.; Hermann, T.; Køber, L.; Torp-Pedersen, C. Tumor Necrosis Factor-Inhibits Insulin's Stimulating Effect on Glucose Uptake and Endothelium-Dependent Vasodilation in Humans. Circulation 2003, 108, 1815-1821. [CrossRef] [PubMed]

84. Carey, A.L.; Febbraio, M.A. Interleukin-6 and insulin sensitivity: Friend or foe? Diabetologia 2004, 47, 1135-1142. [CrossRef] [PubMed]

85. Kiortsis, D.N.; Mavridis, A.K.; Vasakos, S.; Nikas, S.N.; Drosos, A.A. Effects of infliximab treatment on insulin resistance in patients with rheumatoid arthritis and ankylosing spondylitis. Ann. Rheum. Dis. 2005, 64, 765-766. [CrossRef] [PubMed]

86. Huvers, F.C.; Popa, C.; Netea, M.G.; van den Hoogen, F.H.; Tack, C.J. Improved insulin sensitivity by anti-TNFalpha antibody treatment in patients with rheumatic diseases. Ann. Rheum. Dis. 2007, 66, 558-559. [CrossRef] [PubMed]

87. Toms, T.E.; Panoulas, V.F.; John, H.; Douglas, K.M.; Kitas, G.D. Methotrexate therapy associates with reduced prevalence of the metabolic syndrome in rheumatoid arthritis patients over the age of 60-More than just an anti-inflammatory effect? A cross sectional study. Arthritis Res. Ther. 2009, 11, R110. [CrossRef] [PubMed]

88. Toms, T.E.; Panoulas, V.F.; Douglas, K.M.; Griffiths, H.R.; Kitas, G.D. Lack of association between glucocorticoid use and presence of the metabolic syndrome in patients with rheumatoid arthritis: A cross-sectional study. Arthritis Res. Ther. 2008, 10, R145. [CrossRef] [PubMed]

89. Van Sijl, A.M.; Peters, M.J.; Knol, D.L.; de Vet, R.H.; Sattar, N.; Dijkmans, B.A.; Smulders, Y.M.; Nurmohamed, M.T. The Effect of TNF-alpha Blocking Therapy on Lipid Levels in Rheumatoid Arthritis: A Meta-Analysis. Semin. Arthritis Rheum. 2011, 41, 393-400. [CrossRef] [PubMed]

90. Liao, K.P.; Cai, T.; Gainer, V.S.; Cagan, A.; Murphy, S.N.; Liu, C.; Churchill, S.; Shaw, S.Y.; Kohane, I.; Solomon, D.H.; et al. Lipid and Lipoprotein Levels and Trend in Rheumatoid Arthritis Compared to the General Population. Arthritis Care Res. 2013, 65, 2046-2050. [CrossRef] [PubMed]

91. Choy, E.; Sattar, N. Interpreting lipid levels in the context of high-grade inflammatory states with a focus on rheumatoid arthritis: A challenge to conventional cardiovascular risk actions. Ann. Rheum. Dis. 2009, 68, 460-469. [CrossRef] [PubMed] 
92. Charles-Schoeman, C.; Watanabe, J.; Lee, Y.Y.; Furst, D.E.; Amjadi, S.; Elashoff, D.; Park, G.; McMahon, M.; Paulus, H.E.; Fogelman, A.M.; et al. Abnormal function of high-density lipoprotein is associated with poor disease control and an altered protein cargo in rheumatoid arthritis. Arthritis Rheumatol. 2009, 60, 2870-2879. [CrossRef] [PubMed]

93. Filippatos, T.D.; Derdemezis, C.S.; Voulgari, P.V.; Tsimihodimos, V.; Elisaf, M.S.; Tselepis, A.D.; Drosos, A.A. Effects of 12 months of treatment with disease-modifying anti-rheumatic drugs on low and high density lipoprotein subclass distribution in patients with early rheumatoid arthritis: A pilot study. Scand. J. Rheumatol. 2013, 42, 169-175. [CrossRef] [PubMed]

94. Popa, C.; van den Hoogen, F.H.; Radstake, T.R.; Netea, M.G.; Eijsbouts, A.E.; Den Heijer, M.; van der Meer, J.W.; van Riel, P.L.; Stalenhoef, A.F.; Barrera, P. Modulation of lipoprotein plasma concentrations during long-term anti-TNF therapy in patients with active rheumatoid arthritis. Ann. Rheum. Dis. 2007, 66, 1503-1507. [CrossRef] [PubMed]

95. Schimmel, E.K.; Yazici, Y. Increased lipid levels but unchanged atherogenic index in rheumatoid arthritis patients treated with biologic disease modifying antirheumatic drugs: Published experience. Clin. Exp. Rheumatol. 2009, 27, 446-451. [PubMed]

96. Semb, A.G.; Kvien, T.K.; DeMicco, D.A.; Fayyad, R.; Wun, C.C.; LaRosa, J.C.; Betteridge, J.; Pedersen, T.R.; Holme, I. Effect of intensive lipid-lowering therapy on cardiovascular outcome in patients with and those without inflammatory joint disease. Arthritis Rheumatol. 2012, 64, 2836-2846. [CrossRef] [PubMed]

97. Soulaidopoulos, S.; Nikiphorou, E.; Dimitroulas, T.; Kitas, G.D. The Role of Statins in Disease Modification and Cardiovascular Risk in Rheumatoid Arthritis. Front. Med. 2018, 5, 24. [CrossRef] [PubMed]

98. Rontoyanni, V.G.; Sfikakis, P.P.; Kitas, G.D.; Protogerou, A.D. Marine n-3 fatty acids for cardiovascular risk reduction and disease control in rheumatoid arthritis: "kill two birds with one stone"? Curr. Pharm. Des. 2012, 18, 1531-1542. [CrossRef] [PubMed]

99. Elkan, A.C.; Håkansson, N.; Frostegård, J.; Hafström, I. Low level of physical activity in women with rheumatoid arthritis is associated with cardiovascular risk factors but not with body fat mass-A cross sectional study. BMC Musculoskelet. Disord. 2011, 12, 13. [CrossRef] [PubMed]

100. Padyukov, L.; Silva, C.; Stolt, P.; Alfredsson, L.; Klareskog, L. A gene-environment interaction between smoking and shared epitope genes in HLA-DR provides a high risk of seropositive rheumatoid arthritis. Arthritis Rheumatol. 2004, 50, 3085-3092. [CrossRef] [PubMed]

101. Szodoray, P.; Szabó, Z.; Kapitány, A.; Gyetvai, Á.; Lakos, G.; Szántó, S.; Szücs, G.; Szekanecz, Z. Anti-citrullinated protein/peptide autoantibodies in association with genetic and environmental factors as indicators of disease outcome in rheumatoid arthritis. Autoimmun. Rev. 2010, 9, 140-143. [CrossRef] [PubMed]

102. Chung, C.P.; Avalos, I.; Oeser, A.; Gebretsadik, T.; Shintani, A.; Raggi, P.; Stein, C.M. High prevalence of the metabolic syndrome in patients with systemic lupus erythematosus: Association with disease characteristics and cardiovascular risk factors. Ann. Rheum. Dis. 2006, 66, 208-214. [CrossRef] [PubMed]

103. Chung, C.P.; Oeser, A.; Solus, J.F.; Gebretsadik, T.; Shintani, A.; Avalos, I.; Sokka, T.; Raggi, P.; Pincus, T.; Stein, C.M. Inflammation-associated insulin resistance: Differential effects in rheumatoid arthritis and systemic lupus erythematosus define potential mechanisms. Arthritis Rheumatol. 2008, 58, 2105-2112. [CrossRef] [PubMed]

104. Chung, C.P.; Oeser, A.; Solus, J.; Avalos, I.; Gebretsadik, T.; Shintani, A.; Linton, M.F.; Fazio, S.; Stein, C.M. Inflammatory mechanisms affecting the lipid profile in patients with systemic lupus erythematosus. J. Rheumatol. 2007, 34, 1849-1854. [PubMed]

105. Borba, E.F.; Bonfá, E. Dyslipoproteinemias in systemic lupus erythematosus: Influence of disease, activity, and anticardiolipin antibodies. Lupus 1997, 6, 533-539. [CrossRef] [PubMed]

106. Nuttall, S.L.; Heaton, S.; Piper, M.K.; Martin, U.; Gordon, C. Cardiovascular risk in systemic lupus erythematosus-Evidence of increased oxidative stress and dyslipidaemia. Rheumatology 2003, 42, 758-762. [CrossRef] [PubMed]

107. McMahon, M.; Grossman, J.; FitzGerald, J.; Dahlin-Lee, E.; Wallace, D.J.; Thong, B.Y.; Badsha, H.; Kalunian, K.; Charles, C.; Navab, M.; et al. Proinflammatory high-density lipoprotein as a biomarker for atherosclerosis in patients with systemic lupus erythematosus and rheumatoid arthritis. Arthritis Rheumatol. 2006, 54, 2541-2549. [CrossRef] [PubMed] 
108. Papadakis, J.A.; Sidiropoulos, P.I.; Karvounaris, S.A.; Vrentzos, G.E.; Spanakis, E.K.; Ganotakis, E.S.; Kritikos, H.D.; Mikhailidis, D.P.; Boumpas, D.T. High prevalence of metabolic syndrome and cardiovascular risk factors in men with ankylosing spondylitis on anti-TNFalpha treatment: Correlation with disease activity. Clin. Exp. Rheumatol. 2009, 27, 292-298. [PubMed]

109. Mathieu, S.; Gossec, L.; Dougados, M.; Soubrier, M. Cardiovascular profile in ankylosing spondylitis: A systematic review and meta-analysis. Arthritis Care Res. 2011, 63, 557-563. [CrossRef] [PubMed]

110. Labitigan, M.; Bahče-Altuntas, A.; Kremer, J.M.; Reed, G.; Greenberg, J.D.; Jordan, N.; Putterman, C.; Broder, A. Higher rates and clustering of abnormal lipids, obesity, and diabetes mellitus in psoriatic arthritis compared with rheumatoid arthritis. Arthritis Care Res. 2014, 66, 600-607. [CrossRef] [PubMed]

111. Haroon, M.; Gallagher, P.; Heffernan, E.; FitzGerald, O. High Prevalence of Metabolic Syndrome and of Insulin Resistance in Psoriatic Arthritis is Associated with the Severity of Underlying Disease. J. Rheumatol. 2014, 41, 1357-1365. [CrossRef] [PubMed]

112. Costa, L.; Caso, F.; Atteno, M.; Del Puente, A.; Darda, M.A.; Caso, P.; Ortolan, A.; Fiocco, U.; Ramonda, R.; Punzi, L.; et al. Impact of 24-month treatment with etanercept, adalimumab, or methotrexate on metabolic syndrome components in a cohort of 210 psoriatic arthritis patients. Clin. Rheumatol. 2013, 33, 833-839. [CrossRef] [PubMed]

113. Mehta, N.N.; Gelfand, J.M. High-density lipoprotein cholesterol function improves after successful treatment of psoriasis: A step forward in the right direction. J. Investig. Dermatol. 2014, 134, 592-595. [CrossRef] [PubMed]

114. Davignon, J.; Ganz, P. Role of Endothelial Dysfunction in Atherosclerosis. Circulation 2004, 109, III-27-III-32. [CrossRef] [PubMed]

115. Bordy, R.; Totoson, P.; Prati, C.; Marie, C.; Wendling, D.; Demougeot, C. Microvascular endothelial dysfunction in rheumatoid arthritis. Nat. Rev. Rheumatol. 2018. [CrossRef] [PubMed]

116. Tabas, I.; Williams, K.J.; Boren, J. Subendothelial Lipoprotein Retention as the Initiating Process in Atherosclerosis: Update and Therapeutic Implications. Circulation 2007, 116, 1832-1844. [CrossRef] [PubMed]

117. Murdaca, G.; Colombo, B.M.; Cagnati, P.; Gulli, R.; Spanò, F.; Puppo, F. Endothelial dysfunction in rheumatic autoimmune diseases. Atherosclerosis 2012, 224, 309-317. [CrossRef] [PubMed]

118. Libby, P.; Ridker, P.M.; Maseri, A. Inflammation and atherosclerosis. Circulation 2002, 105, 1135-1143. [CrossRef] [PubMed]

119. Steyers, C.; Miller, F. Endothelial Dysfunction in Chronic Inflammatory Diseases. Int. J. Mol. Sci. 2014, 15, 11324-11349. [CrossRef] [PubMed]

120. Dessein, P.H.; Joffe, B.I.; Singh, S. Biomarkers of endothelial dysfunction, cardiovascular risk factors and atherosclerosis in rheumatoid arthritis. Arthritis Res. Ther. 2005, 7, R634-R643. [CrossRef] [PubMed]

121. Dessein, P.H.; Solomon, A.; Woodiwiss, A.J.; Norton, G.R.; Tsang, L.; Gonzalez-Gay, M.A. Marked Independent Relationship between Circulating Interleukin-6 Concentrations and Endothelial Activation in Rheumatoid Arthritis. Mediat. Inflamm. 2013, 2013, 510243. [CrossRef] [PubMed]

122. Gonzalez-Gay, M.A.; Gonzalez-Juanatey, C.; Miranda-Filloy, J.A.; Garcia-Unzueta, M.T.; Llorca, J. Lack of association between carotid intima-media wall thickness and carotid plaques and markers of endothelial cell activation in rheumatoid arthritis patients undergoing anti-TNF therapy. Acta Reumatol. Port. 2012, 37, 155-159. [PubMed]

123. Gonzalez-Gay, M.A.; Garcia-Unzueta, M.T.; De Matias, J.M.; Gonzalez-Juanatey, C.; Garcia-Porrua, C.; Sanchez-Andrade, A.; Martin, J.; Llorca, J. Influence of anti-TNF-alpha infliximab therapy on adhesion molecules associated with atherogenesis in patients with rheumatoid arthritis. Clin. Exp. Rheumatol. 2006, 24, 373-379. [PubMed]

124. Kerekes, G.; Szekanecz, Z.; Dér, H.; Sándor, Z.; Lakos, G.; Muszbek, L.; Csipö, I.; Sipka, S.; Seres, I.; Paragh, G.; et al. Endothelial dysfunction and atherosclerosis in rheumatoid arthritis: A multiparametric analysis using imaging techniques and laboratory markers of inflammation and autoimmunity. J. Rheumatol. 2008, 35, 398-406. [PubMed]

125. Dimitroulas, T.; Hodson, J.; Sandoo, A.; Smith, J.; Kitas, G.D. Endothelial injury in rheumatoid arthritis: A crosstalk between dimethylarginines and systemic inflammation. Arthritis Res. Ther. 2017, $19,32$. [CrossRef] [PubMed]

126. Yao, G.H.; Liu, Z.H.; Zhang, X.; Zheng, C.X.; Chen, H.P.; Zeng, C.H.; Li, L.S. Circulating thrombomodulin and vascular cell adhesion molecule-1 and renal vascular lesion in patients with lupus nephritis. Lupus 2008, 17, 720-726. [CrossRef] [PubMed] 
127. Santos, M.J.; Carmona-Fernandes, D.; Canhão, H.; da Silva, J.C.; Fonseca, J.E.; Gil, V. Early vascular alterations in SLE and RA patients-A step towards understanding the associated cardiovascular risk. PLoS ONE 2012, 7, e44668. [CrossRef] [PubMed]

128. Surdacki, A.; Sulicka, J.; Korkosz, M.; Mikołajczyk, T.; Telesińska-Jasiówka, D.; Klimek, E.; Kierzkowska, I.; Guzik, T.; Grodzicki, T.K. Blood Monocyte Heterogeneity and Markers of Endothelial Activation in Ankylosing Spondylitis. J. Rheumatol. 2014, 41, 481-489. [CrossRef] [PubMed]

129. Genre, F.; López-Mejías, R.; Miranda-Filloy, J.A.; Carnero-López, B.; Gómez-Acebo, I.; Blanco, R.; Ochoa, R.; Rueda, J.; Gonzalez-Juanatey, C.; Llorca, J.; et al. Asymmetric dimethylarginine serum levels in non-diabetic ankylosing spondylitis patients undergoing TNF- $\alpha$ antagonist therapy. Clin. Exp. Rheumatol. 2013, 31, 749-755. [PubMed]

130. Erre, G.L.; Sanna, P.; Zinellu, A.; Ponchietti, A.; Fenu, P.; Sotgia, S.; Carru, C.; Ganau, A.; Passiu, G. Plasma asymmetric dimethylarginine (ADMA) levels and atherosclerotic disease in ankylosing spondylitis: A cross-sectional study. Clin. Rheumatol. 2011, 30, 21-27. [CrossRef] [PubMed]

131. Garg, N.; Krishan, P.; Syngle, A. Atherosclerosis in Psoriatic Arthritis: A Multiparametric Analysis Using Imaging Technique and Laboratory Markers of Inflammation and Vascular Function. Int. J. Angiol. 2016, 25, 222-228. [CrossRef] [PubMed]

132. Kolliker Frers, R.A.; Cosentino, V.; Tau, J.; Kerzberg, E.M.; Urdapilleta, A.; Chiocconi, M.; Kogan, N.; Otero-Losada, M.; Capani, F. Immune-Mediated Inflammation Promotes Subclinical Atherosclerosis in Recent-Onset Psoriatic Arthritis Patients without Conventional Cardiovascular Risk Factors. Front. Immunol. 2018, 9, 139. [CrossRef] [PubMed]

133. Yang, X.; Li, Y.; Li, Y.; Ren, X.; Zhang, X.; Hu, D.; Gao, Y.; Xing, Y.; Shang, H. Oxidative Stress-Mediated Atherosclerosis: Mechanisms and Therapies. Front. Physiol. 2017, 8, 600. [CrossRef] [PubMed]

134. Hassan, S.Z.; Gheita, T.A.; Kenawy, S.A.; Fahim, A.T.; El-Sorougy, I.M.; Abdou, M.S. Oxidative stress in systemic lupus erythematosus and rheumatoid arthritis patients: Relationship to disease manifestations and activity. Int. J. Rheum. Dis. 2011, 14, 325-331. [CrossRef] [PubMed]

135. Vasanthi, P.; Nalini, G.; Rajasekhar, G. Status of oxidative stress in rheumatoid arthritis. Int. J. Rheum. Dis. 2009, 12, 29-33. [CrossRef] [PubMed]

136. García-González, A.; Gaxiola-Robles, R.; Zenteno-Savín, T. Oxidative stress in patients with rheumatoid arthritis. Rev. Investig. Clin. 2015, 67, 46-53.

137. Solmaz, D.; Kozac1, D.; Sarı, İ; Taylan, A.; Önen, F.; Akkoç, N.; Akar, S. Oxidative stress and related factors in patients with ankylosing spondylitis. Eur. J. Rheumatol. 2016, 3, 20-24. [CrossRef] [PubMed]

138. Stanek, A.; Cholewka, A.; Wielkoszyński, T.; Romuk, E.; Sieroń, K.; Sieroń, A. Increased Levels of Oxidative Stress Markers, Soluble CD40 Ligand, and Carotid Intima-Media Thickness Reflect Acceleration of Atherosclerosis in Male Patients with Ankylosing Spondylitis in Active Phase and without the Classical Cardiovascular Risk Factors. Oxid. Med. Cell. Longev. 2017, 2017, 9712536. [CrossRef] [PubMed]

139. Coaccioli, S.; Panaccione, A.; Biondi, R.; Sabatini, C.; Landucci, P.; Del, R.G.; Fantera, M.; Monno, A.M.; Di, L.C.; Paladini, A.; et al. Evaluation of oxidative stress in rheumatoid and psoriatic arthritis and psoriasis. Clin. Ter. 2009, 160, 467-472. [PubMed]

140. Cacciapaglia, F.; Anelli, M.G.; Rizzo, D.; Morelli, E.; Scioscia, C.; Mazzotta, D.; Iannone, F.; Lapadula, G. Influence of TNF- $\alpha$ inhibition on oxidative stress of rheumatoid arthritis patients. Reumatismo 2016, 67, 97-102. [CrossRef] [PubMed]

141. Lundberg, A.M.; Hansson, G.K. Innate immune signals in atherosclerosis. Clin. Immunol. 2010, 134, 5-24. [CrossRef] [PubMed]

142. Witztum, J.L.; Lichtman, A.H. The Influence of Innate and Adaptive Immune Responses on Atherosclerosis. Annu. Rev. Pathol. Mech. Dis. 2014, 9, 73-102. [CrossRef] [PubMed]

143. Adamczak, D.M. The Role of Toll-Like Receptors and Vitamin D in Cardiovascular Diseases-A Review. Int. J. Mol. Sci. 2017, 18, 2252. [CrossRef] [PubMed]

144. Huang, Q.; Pope, R.M. Toll-like receptor signaling: A potential link among rheumatoid arthritis, systemic lupus, and atherosclerosis. J. Leukoc. Biol. 2010, 88, 253-262. [CrossRef] [PubMed]

145. Ospelt, C.; Brentano, F.; Rengel, Y.; Stanczyk, J.; Kolling, C.; Tak, P.P.; Gay, R.E.; Gay, S.; Kyburz, D. Overexpression of toll-like receptors 3 and 4 in synovial tissue from patients with early rheumatoid arthritis: Toll-like receptor expression in early and longstanding arthritis. Arthritis Rheumatol. 2008, 58, 3684-3692. [CrossRef] [PubMed] 
146. Radstake, T.R.; Roelofs, M.F.; Jenniskens, Y.M.; Oppers-Walgreen, B.; van Riel, P.L.; Barrera, P.; Joosten, L.A.; van den Berg, W.B. Expression of Toll-like receptors 2 and 4 in rheumatoid synovial tissue and regulation by proinflammatory cytokines interleukin-12 and interleukin-18 via interferon- $\gamma$ ? Arthritis Rheumatol. 2004, 50, 3856-3865. [CrossRef] [PubMed]

147. Christensen, S.R.; Shupe, J.; Nickerson, K.; Kashgarian, M.; Flavell, R.A.; Shlomchik, M.J. Toll-like receptor 7 and TLR9 dictate autoantibody specificity and have opposing inflammatory and regulatory roles in a murine model of lupus. Immunity 2006, 25, 417-428. [CrossRef] [PubMed]

148. De Rycke, L.; Vandooren, B.; Kruithof, E.; De Keyser, F.; Veys, E.M.; Baeten, D. Tumor necrosis factor alpha blockade treatment down-modulates the increased systemic and local expression of Toll-like receptor 2 and Toll-like receptor 4 in spondylarthropathy. Arthritis Rheumatol. 2005, 52, 2146-2158. [CrossRef] [PubMed]

149. Assassi, S.; Reveille, J.D.; Arnett, F.C.; Weisman, M.H.; Ward, M.M.; Agarwal, S.K.; Gourh, P.; Bhula, J.; Sharif, R.; Sampat, K.; et al. Whole-blood gene expression profiling in ankylosing spondylitis shows upregulation of toll-like receptor 4 and 5. J. Rheumatol. 2011, 38, 87-98. [CrossRef] [PubMed]

150. Candia, L.; Marquez, J.; Hernandez, C.; Zea, A.H.; Espinoza, L.R. Toll-like receptor-2 expression is upregulated in antigen-presenting cells from patients with psoriatic arthritis: A pathogenic role for innate immunity? J. Rheumatol. 2007, 34, 374-379. [PubMed]

151. Schroder, K.; Zhou, R.; Tschopp, J. The NLRP3 Inflammasome: A Sensor for Metabolic Danger? Science 2010, 327, 296-300. [CrossRef] [PubMed]

152. Tedgui, A.; Mallat, Z. Cytokines in Atherosclerosis: Pathogenic and Regulatory Pathways. Physiol. Rev. 2006, 86, 515-581. [CrossRef] [PubMed]

153. Altaf, A.; Qu, P.; Zhao, Y.; Wang, H.; Lou, D.; Niu, N. NLRP3 inflammasome in peripheral blood monocytes of acute coronary syndrome patients and its relationship with statins. Coron. Artery Dis. 2015, 26, 409-421. [CrossRef] [PubMed]

154. Shi, X.; Xie, W.L.; Kong, W.W.; Chen, D.; Qu, P. Expression of the NLRP3 Inflammasome in Carotid Atherosclerosis. J. Stroke Cerebrovasc. Dis. 2015, 24, 2455-2466. [CrossRef] [PubMed]

155. Zheng, F.; Xing, S.; Gong, Z.; Mu, W.; Xing, Q. Silence of NLRP3 Suppresses Atherosclerosis and Stabilizes Plaques in Apolipoprotein E-Deficient Mice. Mediat. Inflamm. 2014, 2014, 507208. [CrossRef] [PubMed]

156. Duewell, P.; Kono, H.; Rayner, K.J.; Sirois, C.M.; Vladimer, G.; Bauernfeind, F.G.; Abela, G.S.; Franchi, L.; Nunez, G.; Schnurr, M.; et al. NLRP3 inflammasomes are required for atherogenesis and activated by cholesterol crystals. Nature 2010, 464, 1357-1361. [CrossRef] [PubMed]

157. Rajamäki, K.; Lappalainen, J.; Öörni, K.; Välimäki, E.; Matikainen, S.; Kovanen, P.T.; Eklund, K.K. Cholesterol crystals activate the NLRP3 inflammasome in human macrophages: A novel link between cholesterol metabolism and inflammation. PLoS ONE 2010, 5, e11765. [CrossRef] [PubMed]

158. Mathews, R.J.; Robinson, J.I.; Battellino, M.; Wong, C.; Taylor, J.C.; Eyre, S.; Churchman, S.M.; Wilson, A.G.; Isaacs, J.D.; Hyrich, K.; et al. Evidence of NLRP3-inflammasome activation in rheumatoid arthritis (RA); genetic variants within the NLRP3-inflammasome complex in relation to susceptibility to RA and response to anti-TNF treatment. Ann. Rheum. Dis. 2014, 73, 1202-1210. [CrossRef] [PubMed]

159. Choulaki, C.; Papadaki, G.; Repa, A.; Kampouraki, E.; Kambas, K.; Ritis, K.; Bertsias, G.; Boumpas, D.T.; Sidiropoulos, P. Enhanced activity of NLRP3 inflammasome in peripheral blood cells of patients with active rheumatoid arthritis. Arthritis Res. Ther. 2015, 17, 257. [CrossRef] [PubMed]

160. Kastbom, A.; Klingberg, E.; Verma, D.; Carlsten, H.; Forsblad-d'Elia, H.; Wesamaa, J.; Cedergren, J.; Eriksson, P.; Söderkvist, P. Genetic variants in CARD8 but not in NLRP3 are associated with ankylosing spondylitis. Scand. J. Rheumatol. 2013, 42, 465-468. [CrossRef] [PubMed]

161. Zhang, H.; Fu, R.; Guo, C.; Huang, Y.; Wang, H.; Wang, S.; Zhao, J.; Yang, N. Anti-dsDNA antibodies bind to TLR4 and activate NLRP3 inflammasome in lupus monocytes/macrophages. J. Transl. Med. 2016, 14, 156. [CrossRef] [PubMed]

162. Kahlenberg, J.M.; Kaplan, M.J. The inflammasome and lupus. Curr. Opin. Rheumatol. 2014, 26, 475-481. [CrossRef] [PubMed]

163. Shin, M.S.; Kang, Y.; Lee, N.; Wahl, E.R.; Kim, S.H.; Kang, K.S.; Lazova, R.; Kang, I. Self double-stranded (ds)DNA induces IL-1 $\beta$ production from human monocytes by activating NLRP3 inflammasome in the presence of anti-dsDNA antibodies. J. Immunol. 2013, 190, 1407-1415. [CrossRef] [PubMed] 
164. Asgari, E.; Le Friec, G.; Yamamoto, H.; Perucha, E.; Sacks, S.S.; Köhl, J.; Cook, H.T.; Kemper, C. C3a modulates IL-1 $\beta$ secretion in human monocytes by regulating ATP efflux and subsequent NLRP3 inflammasome activation. Blood 2013, 122, 3473-3481. [CrossRef] [PubMed]

165. Kahlenberg, J.M.; Thacker, S.G.; Berthier, C.C.; Cohen, C.D.; Kretzler, M.; Kaplan, M.J. Inflammasome Activation of IL-18 Results in Endothelial Progenitor Cell Dysfunction in Systemic Lupus Erythematosus. J. Immunol. 2011, 187, 6143-6156. [CrossRef] [PubMed]

166. Samstad, E.O.; Niyonzima, N.; Nymo, S.; Aune, M.H.; Ryan, L.; Bakke, S.S.; Lappegård, K.T.; Brekke, O.L.; Lambris, J.D.; Damås, J.K.; et al. Cholesterol Crystals Induce Complement-Dependent Inflammasome Activation and Cytokine Release. J. Immunol. 2014, 192, 2837-2845. [CrossRef] [PubMed]

167. Zhao, S.; Chen, H.; Wu, G.; Zhao, C. The association of NLRP3 and TNFRSF1A polymorphisms with risk of ankylosing spondylitis and treatment efficacy of etanercept. J. Clin. Lab. Anal. 2017, 31, e22138. [CrossRef] [PubMed]

168. Hansson, G.K. Inflammation, atherosclerosis, and coronary artery disease. N. Engl. J. Med. 2005, 352, 1685-1695. [CrossRef] [PubMed]

169. Weiss, G.; Willeit, J.; Kiechl, S.; Fuchs, D.; Jarosch, E.; Oberhollenzer, F.; Reibnegger, G.; Tilz, G.P.; Gerstenbrand, F.; Wachter, H. Increased concentrations of neopterin in carotid atherosclerosis. Atherosclerosis 1994, 106, 263-271. [CrossRef]

170. Ray, K.K.; Morrow, D.A.; Sabatine, M.S.; Shui, A.; Rifai, N.; Cannon, C.P.; Braunwald, E. Long-term prognostic value of neopterin: A novel marker of monocyte activation in patients with acute coronary syndrome. Circulation 2007, 115, 3071-3078. [CrossRef] [PubMed]

171. Rho, Y.H.; Solus, J.; Raggi, P.; Oeser, A.; Gebretsadik, T.; Shintani, A.; Stein, C.M. Macrophage activation and coronary atherosclerosis in systemic lupus erythematosus and rheumatoid arthritis. Arthritis Care Res. 2011, 63, 535-541. [CrossRef] [PubMed]

172. Voloshyna, I.; Modayil, S.; Littlefield, M.J.; Belilos, E.; Belostocki, K.; Bonetti, L.; Rosenblum, G.; Carsons, S.E.; Reiss, A.B. Plasma from rheumatoid arthritis patients promotes pro-atherogenic cholesterol transport gene expression in THP-1 human macrophages. Exp. Biol. Med. 2013, 238, 1192-1197. [CrossRef] [PubMed]

173. Li, J.; Fu, Q.; Cui, H.; Qu, B.; Pan, W.; Shen, N.; Bao, C. Interferon- $\alpha$ priming promotes lipid uptake and macrophage-derived foam cell formation: A novel link between interferon- $\alpha$ and atherosclerosis in lupus. Arthritis Rheumatol. 2011, 63, 492-502. [CrossRef] [PubMed]

174. Korman, B.D.; Huang, C.C.; Skamra, C.; Wu, P.; Koessler, R.; Yao, D.; Huang, Q.Q.; Pearce, W.; Sutton-Tyrrell, K.; Kondos, G.; et al. Inflammatory expression profiles in monocyte-to-macrophage differentiation in patients with systemic lupus erythematosus and relationship with atherosclerosis. Arthritis Res. Ther. 2014, 16, R147. [CrossRef] [PubMed]

175. Ghazizadeh, R.; Shimizu, H.; Tosa, M.; Ghazizadeh, M. Pathogenic mechanisms shared between psoriasis and cardiovascular disease. Int. J. Med. Sci. 2010, 7, 284-289. [CrossRef] [PubMed]

176. Ait-Oufella, H.; Taleb, S.; Mallat, Z.; Tedgui, A. Recent advances on the role of cytokines in atherosclerosis. Arterioscler. Thromb. Vasc. Biol. 2011, 31, 969-979. [CrossRef] [PubMed]

177. Ramji, D.P.; Davies, T.S. Cytokines in atherosclerosis: Key players in all stages of disease and promising therapeutic targets. Cytokine Growth Factor Rev. 2015, 26, 673-685. [CrossRef] [PubMed]

178. Svenungsson, E.; Fei, G.Z.; Jensen-Urstad, K.; De Faire, U.; Hamsten, A.; Frostegård, J. TNF- $\alpha$ : A link between hypertriglyceridaemia and inflammation in SLE patients with cardiovascular disease. Lupus 2003, 12, 454-461. [CrossRef] [PubMed]

179. Ley, K.; Laudanna, C.; Cybulsky, M.I.; Nourshargh, S. Getting to the site of inflammation: The leukocyte adhesion cascade updated. Nat. Rev. Immunol. 2007, 7, 678-689. [CrossRef] [PubMed]

180. Folcik, V.A.; Aamir, R.; Cathcart, M.K. Cytokine modulation of LDL oxidation by activated human monocytes. Arterioscler. Thromb. Vasc. Biol. 1997, 17, 1954-1961. [CrossRef] [PubMed]

181. Didion, S. Cellular and Oxidative Mechanisms Associated with Interleukin-6 Signaling in the Vasculature. Int. J. Mol. Sci. 2017, 18, 2563. [CrossRef] [PubMed]

182. Kang, Y.J.; Kim, W.J.; Bae, H.U.; Kim, D.I.; Park, Y.B.; Park, J.E.; Kwon, B.S.; Lee, W.H. Involvement of TL1A and DR3 in induction of pro-inflammatory cytokines and matrix metalloproteinase-9 in atherogenesis. Cytokine 2005, 29, 229-235. [CrossRef] [PubMed] 
183. McLaren, J.E.; Calder, C.J.; McSharry, B.P.; Sexton, K.; Salter, R.C.; Singh, N.N.; Wilkinson, G.W.; Wang, E.C.; Ramji, D.P. The TNF-Like Protein 1A-Death Receptor 3 Pathway Promotes Macrophage Foam Cell Formation In Vitro. J. Immunol. 2010, 184, 5827-5834. [CrossRef] [PubMed]

184. Steiner, G.; Tohidast-Akrad, M.; Witzmann, G.; Vesely, M.; Studnicka-Benke, A.; Gal, A.; Kunaver, M.; Zenz, P.; Smolen, J.S. Cytokine production by synovial T cells in rheumatoid arthritis. Rheumatology 1999, 38, 202-213. [CrossRef] [PubMed]

185. Cavagna, L.; Boffini, N.; Cagnotto, G.; Inverardi, F.; Grosso, V.; Caporali, R. Atherosclerosis and Rheumatoid Arthritis: More Than a Simple Association. Mediat. Inflamm. 2012, 2012, 147354. [CrossRef] [PubMed]

186. Pasceri, V.; Yeh, E.T. A tale of two diseases: Atherosclerosis and rheumatoid arthritis. Circulation 1999, 100, 2124-2126. [CrossRef] [PubMed]

187. Skeoch, S.; Bruce, I.N. Atherosclerosis in rheumatoid arthritis: Is it all about inflammation? Nat. Rev. Rheumatol. 2015, 11, 390-400. [CrossRef] [PubMed]

188. Cassatella, M.A.; da Silva, G.P.; Tinazzi, I.; Facchetti, F.; Scapini, P.; Calzetti, F.; Tamassia, N.; Wei, P.; Nardelli, B.; Roschke, V.; et al. Soluble TNF-like cytokine (TL1A) production by immune complexes stimulated monocytes in rheumatoid arthritis. J. Immunol. 2007, 178, 7325-7333. [CrossRef] [PubMed]

189. Bamias, G.; Siakavellas, S.I.; Stamatelopoulos, K.S.; Chryssochoou, E.; Papamichael, C.; Sfikakis, P.P. Circulating levels of TNF-like cytokine 1A (TL1A) and its decoy receptor 3 (DcR3) in rheumatoid arthritis. Clin. Immunol. 2008, 129, 249-255. [CrossRef] [PubMed]

190. Bamias, G.; Stamatelopoulos, K.; Zampeli, E.; Protogerou, A.; Sigala, F.; Papamichael, C.; Christopoulos, P.; Kitas, G.D.; Sfikakis, P.P. Circulating levels of TNF-like cytokine 1A correlate with the progression of atheromatous lesions in patients with rheumatoid arthritis. Clin. Immunol. 2013, 147, 144-150. [CrossRef] [PubMed]

191. McGrath, C.M.; Young, S.P. Lipid and Metabolic Changes in Rheumatoid Arthritis. Curr. Rheumatol. Rep. 2015, 17, 57. [CrossRef] [PubMed]

192. Daïen, C.I.; Duny, Y.; Barnetche, T.; Daurès, J.P.; Combe, B.; Morel, J. Effect of TNF inhibitors on lipid profile in rheumatoid arthritis: A systematic review with meta-analysis. Ann. Rheum. Dis. 2012, 71, 862-868. [CrossRef] [PubMed]

193. Obermoser, G.; Pascual, V. The interferon- $\alpha$ signature of systemic lupus erythematosus. Lupus 2010, 19, 1012-1019. [CrossRef] [PubMed]

194. Wigren, M.; Nilsson, J.; Kaplan, M.J. Pathogenic immunity in systemic lupus erythematosus and atherosclerosis: Common mechanisms and possible targets for intervention. J. Intern. Med. 2015, 278, 494-506. [CrossRef] [PubMed]

195. Zhang, C.Y.; Qu, B.; Ye, P.; Li, J.; Bao, C.D. Vulnerability of atherosclerotic plaques is associated with type I interferon in a murine model of lupus and atherosclerosis. Genet. Mol. Res. 2015, 14, 14871-14881. [CrossRef] [PubMed]

196. Sumarac-Dumanovic, M.; Stevanovic, D.; Ljubic, A.; Jorga, J.; Simic, M.; Stamenkovic-Pejkovic, D.; Starcevic, V.; Trajkovic, V.; Micic, D. Increased activity of interleukin-23/interleukin-17 proinflammatory axis in obese women. Int. J. Obes. 2009, 33, 151-156. [CrossRef] [PubMed]

197. Fabbrini, E.; Cella, M.; Mccartney, S.A.; Fuchs, A.; Abumrad, N.A.; Pietka, T.A.; Chen, Z.; Finck, B.N.; Han, D.H.; Magkos, F.; et al. Association between specific adipose tissue CD4+ T-cell populations and insulin resistance in obese individuals. Gastroenterology 2013, 145, 366-374. [CrossRef] [PubMed]

198. Westlake, S.L.; Colebatch, A.N.; Baird, J.; Kiely, P.; Quinn, M.; Choy, E.; Ostor, A.J.; Edwards, C.J. The effect of methotrexate on cardiovascular disease in patients with rheumatoid arthritis: A systematic literature review. Rheumatology 2010, 49, 295-307. [CrossRef] [PubMed]

199. Vlachopoulos, C.; Gravos, A.; Georgiopoulos, G.; Terentes-Printzios, D.; Ioakeimidis, N.; Vassilopoulos, D.; Stamatelopoulos, K.; Tousoulis, D. The effect of TNF-A antagonists on aortic stiffness and wave reflections: A meta-analysis. Clin. Rheumatol. 2018, 37, 515-526. [CrossRef] [PubMed]

200. Protogerou, A.D.; Zampeli, E.; Fragiadaki, K.; Stamatelopoulos, K.; Papamichael, C.; Sfikakis, P.P. A pilot study of endothelial dysfunction and aortic stiffness after interleukin-6 receptor inhibition in rheumatoid arthritis. Atherosclerosis 2011, 219, 734-736. [CrossRef] [PubMed]

201. Tam, L.-S.; Kitas, G.D.; Gonzalez-Gay, M.A. Can suppression of inflammation by anti-TNF prevent progression of subclinical atherosclerosis in inflammatory arthritis? Rheumatology 2014, 53, 1108-1119. [CrossRef] [PubMed] 
202. Low, A.S.; Symmons, D.P.; Lunt, M.; Mercer, L.K.; Gale, C.P.; Watson, K.D.; Dixon, W.G.; Hyrich, K.L. British Society for Rheumatology Biologics Register for Rheumatoid Arthritis (BSRBR-RA) and the BSRBR Control Centre Consortium, Relationship between exposure to tumour necrosis factor inhibitor therapy and incidence and severity of myocardial infarction in patients with rheumatoid arthritis. Ann. Rheum. Dis. 2017, 76, 654-660. [CrossRef] [PubMed]

203. Roubille, C.; Richer, V.; Starnino, T.; McCourt, C.; McFarlane, A.; Fleming, P.; Siu, S.; Kraft, J.; Lynde, C.; Pope, J.; Gulliver, W. The effects of tumour necrosis factor inhibitors, methotrexate, non-steroidal anti-inflammatory drugs and corticosteroids on cardiovascular events in rheumatoid arthritis, psoriasis and psoriatic arthritis: A systematic review and meta-analysis. Ann. Rheum. Dis. 2015, 74, 480-489. [CrossRef] [PubMed]

204. Ketelhuth, D.F.J.; Hansson, G.K. Modulation of autoimmunity and atherosclerosis—common targets and promising translational approaches against disease. Circ. J. 2015, 79, 924-933. [CrossRef] [PubMed]

205. Koga, M.; Kai, H.; Yasukawa, H.; Yamamoto, T.; Kawai, Y.; Kato, S.; Kusaba, K.; Kai, M.; Egashira, K.; Kataoka, Y.; Imaizumi, T. Inhibition of Progression and Stabilization of Plaques by Postnatal Interferon-Function Blocking in ApoE-Knockout Mice. Circ. Res. 2007, 101, 348-356. [CrossRef] [PubMed]

206. Ridker, P.M.; Everett, B.M.; Thuren, T.; MacFadyen, J.G.; Chang, W.H.; Ballantyne, C.; Fonseca, F.; Nicolau, J.; Koenig, W.; Anker, S.D.; et al. Antiinflammatory Therapy with Canakinumab for Atherosclerotic Disease. N. Engl. J. Med. 2017, 377, 1119-1131. [CrossRef] [PubMed]

207. Dessein, P.H.; Tsang, L.; Woodiwiss, A.J.; Norton, G.R.; Solomon, A. Circulating Concentrations of the Novel Adipokine Chemerin Are Associated with Cardiovascular Disease Risk in Rheumatoid Arthritis. J. Rheumatol. 2014, 41, 1746-1754. [CrossRef] [PubMed]

208. Makrilakis, K.; Fragiadaki, K.; Sfikakis, P.P.; Kitas, G.D. Chemerin and Cardiovascular Risk in Rheumatoid Arthritis after Interleukin 6 Receptor Blockade. J. Rheumatol. 2015, 42, 349. [CrossRef] [PubMed]

209. Thomas, G.; Mancini, J.; Jourde-Chiche, N.; Sarlon, G.; Amoura, Z.; Harlé, J.R.; Jougla, E.; Chiche, L. Mortality Associated With Systemic Lupus Erythematosus in France Assessed by Multiple-Cause-of-Death Analysis. Arthritis Rheumatol. 2014, 66, 2503-2511. [CrossRef] [PubMed]

210. Elfving, P.; Puolakka, K.; Kautiainen, H.; Virta, L.J.; Pohjolainen, T.; Kaipiainen-Seppänen, O. Mortality and causes of death among incident cases of systemic lupus erythematosus in Finland 2000-2008. Lupus 2014, 23, 1430-1434. [CrossRef] [PubMed]

211. Wong, K.; Gladman, D.D.; Husted, J.; Long, J.A.; Farewell, V.T.; Long, J.A. Mortality studies in psoriatic arthritis: Results from a single outpatient clinic. I. Causes and risk of death. Arthritis Rheum. 1997, 40, 1868-1872. [CrossRef] [PubMed]

212. Ali, Y.; Tom, B.D.; Schentag, C.T.; Farewell, V.T.; Gladman, D.D. Improved survival in psoriatic arthritis with calendar time. Arthritis Rheumatol. 2007, 56, 2708-2714. [CrossRef] [PubMed]

213. Mathieu, S.; Pereira, B.; Soubrier, M. Cardiovascular events in ankylosing spondylitis: An updated meta-analysis. Semin. Arthritis Rheum. 2015, 44, 551-555. [CrossRef] [PubMed]

214. Wainstein, M.V.; Mossmann, M.; Araujo, G.N.; Gonçalves, S.C.; Gravina, G.L.; Sangalli, M.; Veadrigo, F.; Matte, R.; Reich, R.; Costa, F.G.; et al. Elevated serum interleukin-6 is predictive of coronary artery disease in intermediate risk overweight patients referred for coronary angiography. Diabetol. Metab. Syndr. 2017, 9, 67. [CrossRef] [PubMed]

215. Lin, Y.H.; Glei, D.; Weinstein, M.; Wu, S.I.; Chien, K.L. Additive value of interleukin-6 and C-reactive protein in risk prediction for all-cause and cardiovascular mortality among a representative adult cohort in Taiwan. J. Formos. Med. Assoc. 2017, 116, 982-992. [CrossRef] [PubMed]

(C) 2018 by the authors. Licensee MDPI, Basel, Switzerland. This article is an open access article distributed under the terms and conditions of the Creative Commons Attribution (CC BY) license (http:/ / creativecommons.org/licenses/by/4.0/). 